\title{
What next? Rewilding as a radical future for the British countryside
}

\author{
Christopher J. Sandom and David W. Macdonald
}

Feral is, in part, a counter-factual: it imagines the lives we no longer lead but might, the species that no longer exist but could, and the faculties we no longer engage but should.

\section{George Monbiot}

\subsection{Introduction}

Many of the chapters in this book have been about understanding the interface between agriculture in the British landscape, and how to conserve Nature. Indeed, the extent to which that understanding has advanced since Britain became part of the Common Agricultural Policy in 1973, or since we first asked farmers in 1981 what they thought about wildlife on their farms (Macdonald and Johnson 2000; Macdonald and Feber 2015: Chapter 14), is extraordinary. The WildCRU is proud to have played its part, along with many others, in that journey, as described in this book. That said, to borrow from the title of Chris Patten's (2009) book about the future of nation states: 'What next?'. Many of the countryside's ailments remain the same, so certainly there is great value in prescribing more of the same: better evidence-based solutions, packaged within creative policies to hold the line for Nature. However, Patten's answer for the future of nation states (which, after all, are directly relevant, being the operational units that formulate and deliver the environmental policy that will shape both food production and nature conservation in the countryside) was to look for realistically radical leaps to a better future. That is what we aim to do for Nature in this chapter.

A good starting point is to remember, as we describe in Chapter 1, that everything is connected to everything else, that when it comes to conservation, biology is necessary but not sufficient, and what is needed is extreme interdisciplinarity that weds the natural and social sciences and the environmental and human dimensions of the countryside. While many attributes of
Nature defy monetization, it is simultaneously the case that valuing Nature is an irresistible common denominator in audits of policy options (TEEB 2010). An insightful analogy is that of the circular economy, where waste is considered as a valuable resource rather than an expensive burden (Benyus 2009; Macarthur 2013). In circular economies, and in functioning ecosystems, energy and nutrients cycle.

Turning to that radical future, we think back with legitimate nostalgia to wonderful elements of the longlost wild past. Large mammals have a special place in many human value systems (Macdonald et al. 2013), so think of the wolves Canis lupus, lynx Lynx lynx, and even bear Ursus arctos that once thrived here beside our recent ancestors, along with wild boar Sus scrofa (Fig 16.1), beaver Castor fiber, and elk Alces alces. There is nothing irrational or foolishly sentimental in seeking inspiration from these animals for a radical future, inspiration with a hard-nosed, science-based, and policy-relevant character. Our goal is not to recreate the past, but rather to build a present informed by the past and fit for the future (Macdonald 2009). Furthermore, thinking about the future is not an undisciplined self-indulgence, but a responsible (indeed essential) activity, itself shaped by carefully devised rules and procedures that takes an informed look at how things might be, say, 40 years from now, and asks how each plausible scenario might affect society's planning for the future of the countryside (Kass et al. 2011). It is in this spirit that we turn to the question: What next?

First, let us define our scope and terms. In our radical future we have identified three aims for the national ecosystem: (1) it supports native biodiversity, 


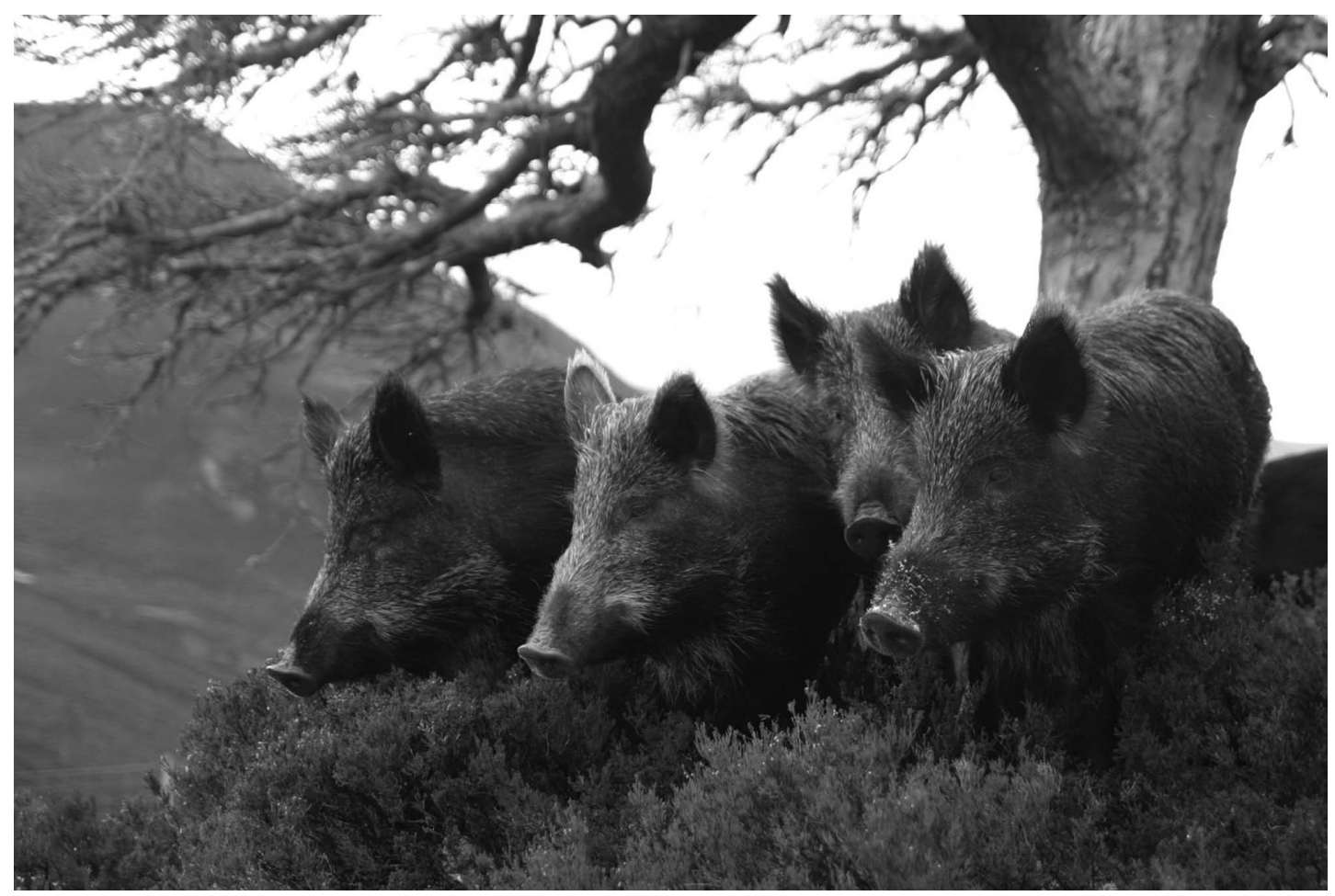

Figure 16.1 Alladale Wilderness Reserve with wild boar Sus scrofa. (C) C. Sandom.

(2) it is a bountiful resource of ecosystem services, and

(3) it is as self-sustaining as possible. These goals are well aligned with the government's ambition to be the first generation to leave the natural environment in a better state than when it was inherited (Defra 2011). However, none of our stated goals are currently being met. The State of Nature report highlighted that, of 3148 species investigated, $60 \%$ have declined in the last 50 years (Burns et al. 2013), and the National Ecosystem Assessment reported 30\% of ecosystem services are deteriorating in Britain (National Ecosystem Service Assessment 2011a), despite current conservation efforts. To achieve our goals, ecological restoration is required and to achieve this we turn to rewilding as one radical answer. Ecological restoration is 'the process of assisting the recovery of an ecosystem that has been degraded, damaged, or destroyed' (SER 2004). Unfortunately, clear and broadly applicable guidelines for delivering such assistance have not been forthcoming, reflecting the difficulty ecologists have had in developing community assembly rules (Keddy and Weiher 2001). As a result, restoration ecologists have largely left internal ecosystem dynamics as black boxes and focused on restoring appropriate ecological filters, particularly environmental conditions (Belyea 2004), in the community assembly chain (see Fig. 16.2). Understanding these internal ecosystem dynamics as best we can will help practitioners design more effective and efficient restoration projects, and it is in this context that rewilding has become a key discussion point.

Rewilding received its first formal description by Soulé and Noss (1998) as a mechanism for conserving biodiversity using (1) large core protected areas, (2) connectivity between them, and (3) the reintroduction of keystone species, particularly large predators. The conservation value of well-connected large protected areas was illuminated by the theory of island biogeography (MacArthur and Wilson 1967), and large predators received special attention because of their importance in driving trophic cascades and their need of large and connected reserves (Terborgh and Estes 2010). More recently, the keystone species element emerges as particularly important and rewilding has come to mean species reintroduction designed to reestablish a lost or impoverished ecological process, as opposed to being motivated solely to preserve the returned species, although the distinction is sometimes fuzzy (Sandom et al. 2013b). In essence, in rewilding, 
species' function is prioritized over form. A complete suite of ecological processes links the working parts of a fully functioning ecosystem, thus rewilding can be defined as community (re-) assembly to restore ecosystem function. Restoring all natural processes is perhaps rewilding in its purest sense, but we see rewilding as a continuum where almost any landscape could be rewilded to some extent. This continuum is captured within the concepts of core areas and connectivity, with core areas supporting purer rewilding where completely functional and biodiverse ecosystems are prioritized, while rewilding in the intervening productive landscapes seeks to restore natural processes in a landscape of human endeavour to balance biodiversity, ecosystem services, and self-sustainability. A good balance will allow the land to be productive while also ensuring connectivity between core areas supporting biodiversity and self-sustainability.

Rewilding challenges practitioners to understand how past, present, and future human activity has, is, and will affect ecosystem function, and to take appropriate remedial action where possible (Fig. 16.2). Because there is no single point in history that should be recreated, rewilding focuses on re-establishing naturally dynamic processes that, through an appropriate sequence of species reintroductions, attempt to move the ecosystem towards a more appropriately biodiverse and functional state that is self-sustaining in the present climate, and that projected for the near future (Fig. 16.3). Ultimately, in core areas, rewilding practitioners should be attempting to restore community components that will restore local ecosystems to a totipotent state, which determines their own shifting form and creates a complex mosiac of conditions that supports biodiversity, while in productive landscapes processes are restored to support ecosystem services and biodiversity. As we turn to this radical future we are teetering on the cutting edge of applied ecological theory, but even so, the restoration of species communities, and with them critical processes, is already bringing successes (Terborgh and Estes 2010; Estes et al. 2011).

Rewilding Britain is a challenging prospect. As an island, densely populated for the most part, finding space to establish large core areas and connecting them is difficult (Lawton et al. 2010). Furthermore, the British ecosystem has been heavily impacted by people for millennia. This creates difficulties in determining what processes have been lost and which are functioning insufficiently or too vociferously. It also means it has been many generations since the British public lived alongside wild and functioning ecosystems with, for

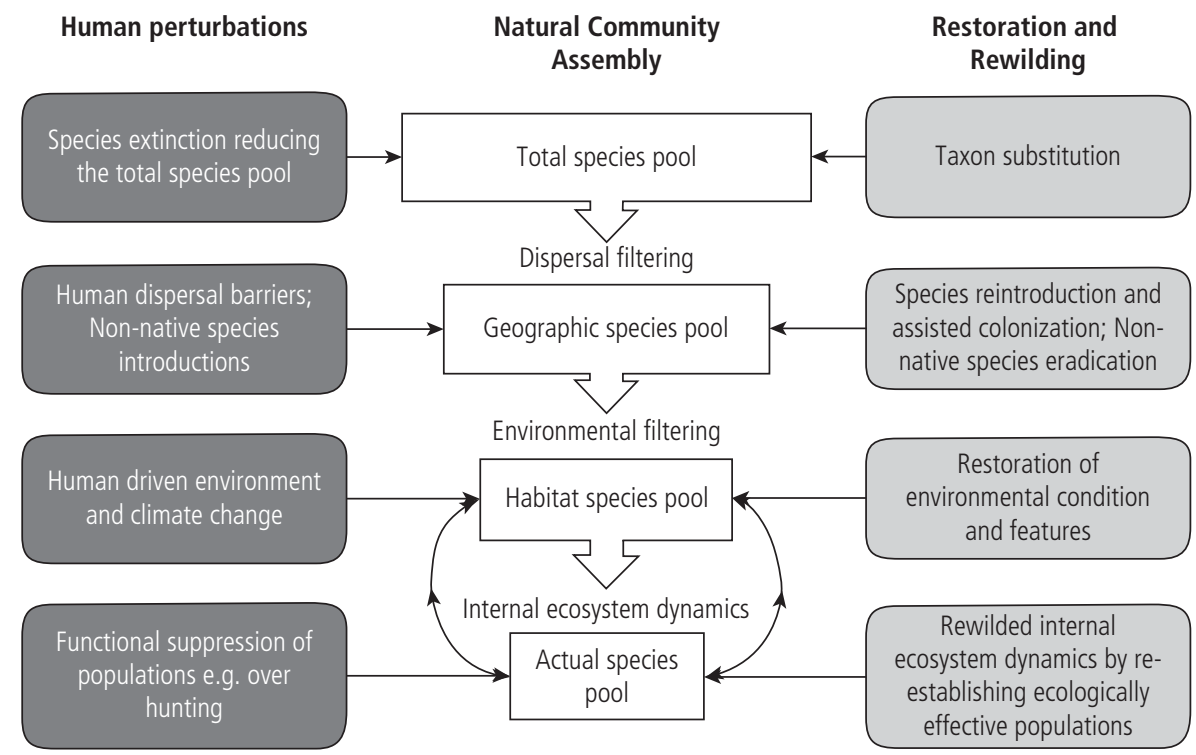

Figure 16.2 Conceptual framework of the relationship between the natural community assembly chain (centre), human drivers of ecosystem perturbation (left), and tools of restoration and rewilding to counter these perturbations (right). Traditionally, ecological restoration has targeted the restoration of appropriate environmental filtering and left the internal ecosystem dynamics as a black box. Rewilding requires the understanding and restoration of the internal dynamics; this is especially important when perturbations of the internal dynamics are a driving force for change in the ecological conditions. Community assembly chain adapted from Keddy and Weiher (2001) and Belyea (2004). 


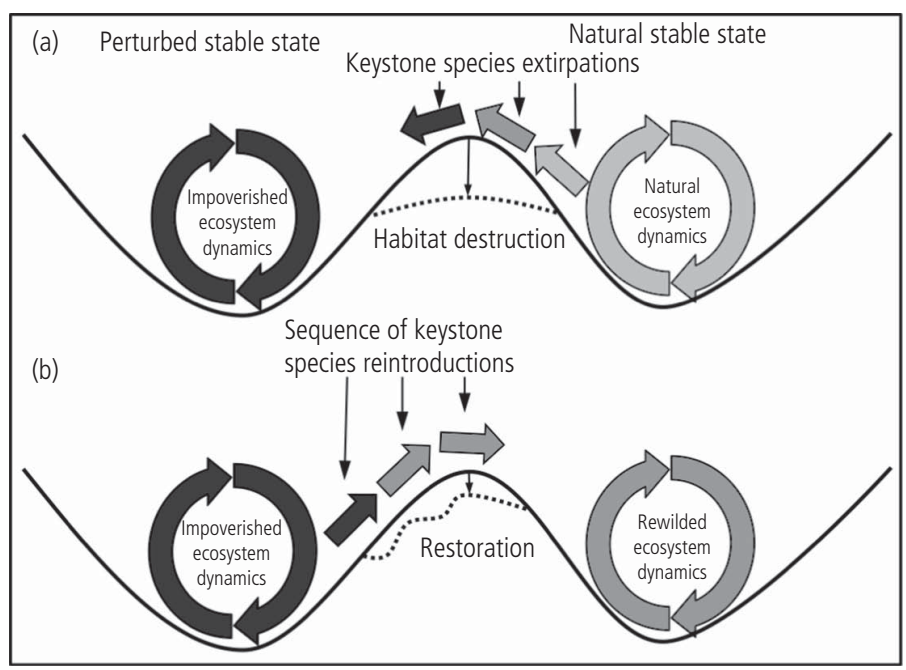

Figure 16.3 A graphical depiction of how rewilding and restoration fit within the 'alternative stable states' community assembly model. (a) A naturally functioning stable state ecosystem is moved to an alternative stable state through a combination of species extirpations and habitat destruction. (b) To achieve effective (target driven) and efficient (cost effective and long-term benefits) restoration, it is necessary to restore the internal ecosystem dynamics through species reintroduction that will naturally move the ecosystem towards a more diverse stable state. Restoration of environmental conditions can be used as short-term direct management to facilitate the reintroduction of keystone species.

example, complete communities of the large predators. Large mammalian predators, indeed large mammals in general, are at the forefront of the rewilding agenda because they have been so heavily persecuted, persecuted to the extent that they have been eradicated or functionally removed from most developed countries (Sandom et al. 2013a; Sandom et al. 2014a). Through trophic interactions, predators are intricately linked to the functioning of ecosystems (Smith et al. 2003) and so are important factors in supporting biodiversity. Because of their importance, past persecution, and present controversies we will focus on the feasibility of restoring some of the processes delivered by large mammals to Britain.

The Scottish Highlands have received greater attention than England and Wales for rewilding to date because the possibility of creating a large core area is more feasible there, due to the lower population density and land ownership structure that allow large areas to come under single land management policies. In this chapter, we will apply this experience to the whole of Britain by exploring the current state of the wild in Britain, whether a land sparing, sharing, or a combined land management structure offers the best opportunities to achieve our goals, and how three key processes, provided by large mammals, can be restored to Britain.

\subsection{State of the wild in Britain}

In previous interglacials similar to the Holocene, Western Europe, including Britain, is thought to have supported a wooded landscape (Svenning 2002). However, the degree to which this woodland was primarily closed, open, or heterogenous is highly contentious. The prevailing wisdom has been that it was primarily closed, although including some open patches (for a review see Svenning 2002), but this is challenged by the observations of Frans Vera at one of the world's early rewilding projects, Oostvaardersplassen (Vera 2000).

Oostvaardersplassen is a fenced area of reclaimed land in the Netherlands, not far from Amsterdam, that covers 6000 ha (including some open water). It has been allowed to go wild since the nature reserve was formed in 1968, and, importantly, part of the lost large herbivore guild, including Heck cattle and Konik horses, has been re-established and largely governs itself, bar human intervention to ease animal welfare concerns (Vera 2009). Frans Vera posited that large herbivores are a key factor in determining vegetation dynamics, creating a diverse mosiac of open, closed, and re-vegetating habitats through grazing, in combination with other natural processes (Vera 2000). It is an important hypothesis but one that, in Britain, is not strongly supported by pollen and beetle data for the early Holocene ( 10 000 to 5000 years BP), prior to agriculture (Mitchell 2005; Whitehouse and Smith 2010). Evidence from beetles indicates relatively low herbivore abundances and relatively high tree cover during this period (Sandom et al. 2014b). In contrast, the Last Interglacial (Eemian, 132 000 to 110000 years $\mathrm{BP})$ does appear to indicate greater herbivore densities and more mixed open and closed vegetation mosiacs, reflecting Vera's hypothesis (Sandom et al. 2014b). No modern humans were in Britain during previous interglacials and there was a full compliment of megafauna 
that may have been instrumental in driving the vegetation dynamics (Sandom et al. 2014b). In this regard, despite uncertainty in past environment reconstructions, a mixed mosaic of open and closed vegetation communities may be considered as the ecological and evolutionary history of the wild British landscape that will support Britain's native biodiversity.

With the dawn of agriculture, the balance shifted back from the primarily closed woodland of the early Holocene to a greater mosiac of open, wood-pasture, and closed habitats, as land was actively cleared for agriculture and domesticated livestock were reared more extensively (Sandom et al. 2014b). Interestingly, this period may have more closely reflected interglacial vegetation structure prior to modern human arrival than the early Holocene. The negative impacts on biodiversity of the industrial revolution that allowed industrial-scale agriculture have seen the homogenization of the landscape, removing wooded areas and replacing them with open agricultural landscapes. Seventy-five per cent of Britain is now cultivated (Morton et al. 2011). Twelve per cent of the UK is woodland but only c. $2.3 \%$ is ancient woodland (Forestry Commission 2012). The lack of woodland, particularly mature woodland, appears to be strongly linked to the loss of biodiversity in Britain, with $40 \%$ of the species lost since 1800 associated with this habitat, considerably more than any other single habitat type (Hambler et al. 2011). Woodlands also provide a variety of ecosystem services such as improving air, soil, and water quality, and reducing the risk of flooding and, while almost all these services are currently increasing, they are doing so from a highly depressed baseline (National Ecosystem Service Assessment 2011b). Thus, there is a pressing imperative to consider woodland regeneration processes. In this chapter we will do this, by exploring the current state of processes related to woodland regeneration, and considering Britain's mammal community to see if we can identify a sequence of mammal reintroductions to restore key processes and thus lead to a more biodiverse and self sustaining British ecosystem. We do this by following the community assembly chain as outlined in Figure 16.2 to determine which functional guilds in the mammal community are either over or under represented. This is a four-step process starting with the total global mammal species pool and ending with the local internal ecosystem dynamics.

\subsubsection{Total mammal species pool (global)}

The Pleistocene megafauna extinction had important implications for vegetation structure and corresponding processes. In Great Britain, 13 species of large mammal ${ }^{1}$ became either globally extinct or were continentally lost between the last interglacial ( 132 000 years Before Present: BP) to 1000 years BP, with modern humans the most likely cause (Sandom et al. 2014a), abetted by climate change (Yalden and Barrett 1999). These extinctions removed incumbents of the large predator ( $\geq 10 \mathrm{~kg}, 3$ species), mega-herbivore $(\geq 1000 \mathrm{~kg}, 6$ species), large herbivore $(\geq 10 \mathrm{~kg}, 2$ species), and large omnivore ( 2 species) functional guilds (Fig. 16.4), leaving the largest predator and herbivore guilds completely unpopulated.

\subsubsection{Geographic and habitat species pools (Britain)}

A further suite of extirpations removed brown bear, wolf, lynx, aurochsen Bos primigenius, elk, wild boar, and beaver from Great Britain during the Holocene, but they survive elsewhere in Europe (horse and reindeer were possibly lost to climate change, with small populations, respectively, returned to the New Forest and the Cairngorms). Many of these species are making their own way back across Europe (Enserink and Vogel 2006), but would need a lift to the UK, as beaver and wild boar have. Introduced non-native mammalian species have crossed the Channel with human assistance (see Fig. 16.4), often problematically (see Macdonald and Feber 2015: Chapters 6 and 8), swelling the ranks of the unpredated medium/large herbivores (Fig. 16.4), while others have become what Macdonald and Burnham (2010) term 'ecological citizens' (Macdonald and Feber 2015: Chapters 1 and 11).

Britain is now dominated by open agricultural and moorland habitats with limited native woodland communities. As a result, there is limited habitat available for woodland associated species such as lynx, wild boar, beaver, and elk, affecting their suitability to be reintroduced in most regions, and there is a continued threat to woodland dependent species (Hambler et al. 2011).

\footnotetext{
1 Woolly rhinoceros Coelodonta antiquitatis ${ }^{M H}$, spotted hyaena Crocuta crocuta $^{* L P}$, straight-tusked elephant Elephas antiquus $^{* M H}$, hippopotamus Hippopotamus amphibius ${ }^{* M H}$, Neanderthal Homo neanderthalensis ${ }^{L O}$, scimitar-toothed cat Homotherium latidens ${ }^{L P}$, woolly mammoth Mammuthus primigenius $^{M H}$, Irish elk Megaloceros giganteus ${ }^{L H}$, muskox Ovibos moschatus $^{L H}$, cave lion Panthera spelaea ${ }^{* L P}$, narrow-nosed rhinoceros Stephanorhinus hemitoechus ${ }^{M H}$, Merck's rhinoceros Stephanorhinus kirchbergensis ${ }^{* M H}$, cave bear Ursus spelaeus ${ }^{L O}$ : * = reintroduction or taxon substitution consideration possible, ${ }^{\mathrm{MH}}=$ megaherbivore, ${ }^{\mathrm{LP}}=$ large predator, ${ }^{\mathrm{LO}}=$ large omnivore, ${ }^{\mathrm{LH}}=$ large herbivore
} 


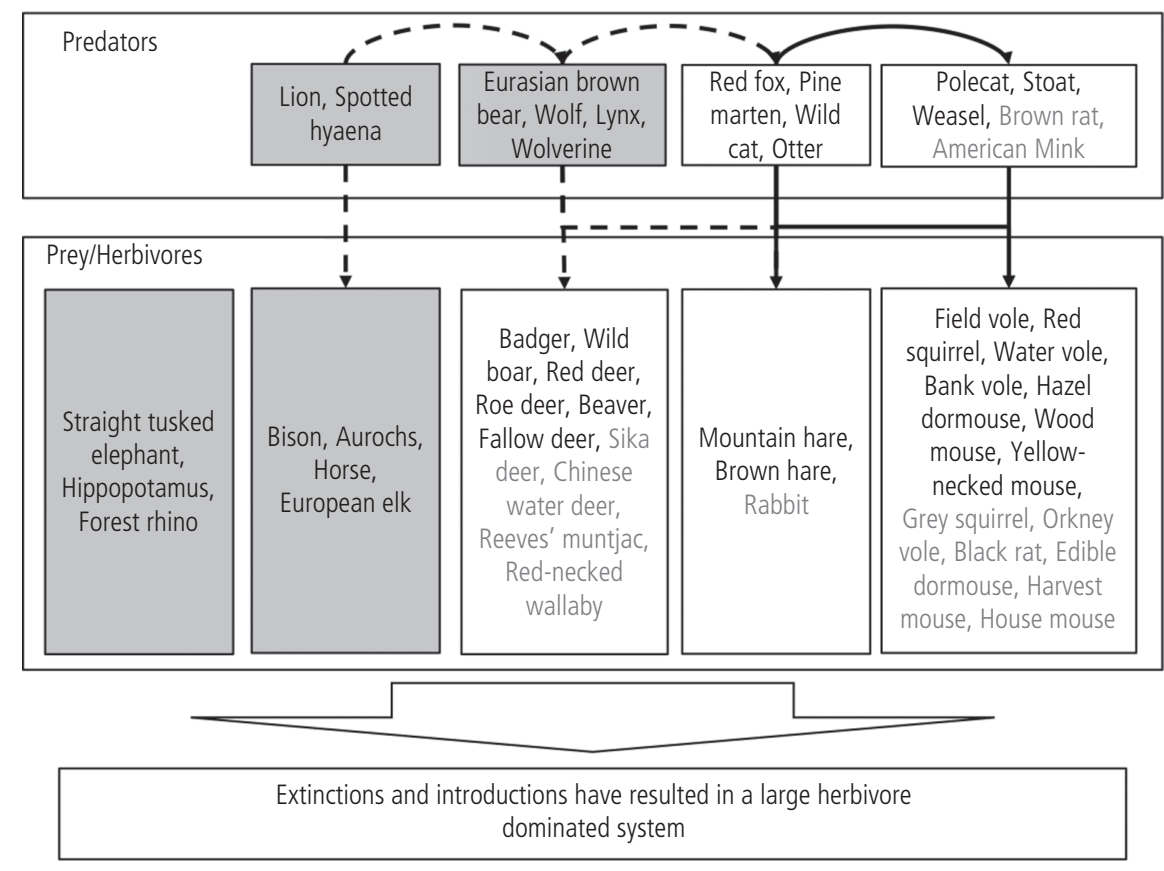

Figure 16.4 Mammalian food web structure in the UK, including all species that have been present in the UK since the Last Interglacial, except those thought to be unsuited to current climatic conditions e.g. mammoth. Grey boxes indicate extinct guilds. Grey lettering indicates introduced species. The fallow deer Dama dama is an example of Pleistocene rewilding as it is a species present during the Last Interglacial but reintroduced to Britain, most likely by the Normans (Yalden and Barrett 1999; Sykes 2004). Schematic is divided into two broad guilds. Boxes within these guilds group species by body size, going from large to small from left to right. Arrows indicate likely strong interactions, solid and dotted lines indicate current and lost interactions respectively. Competition within the predator guild is summarized with larger species limiting smaller species. Continentally and globally extinct species are included if it is possible they or a taxon substitute could conceivably be reintroduced, even if it is currently unworkable in reality.

\subsubsection{Internal ecosystem dynamics (regional)}

Humans directly impact the ecological effectiveness of particular functional guilds. Most land is under management, whether it appears wild or not. For instance, large tracts of land in the Scottish Highlands are managed for game sports (Warren 2009), red deer Cervus elaphus (Fig. 16.5) being a key species (but not the only species) that is suppressing natural woodland regeneration (Hobbs 2009). High densities of large deer are less prevelant in England and Wales (Macdonald and Tattersall 2001), although fallow deer Dama dama are widely distributed in these countries and their population is expanding (Ward 2005). Smaller cervids, such as roe deer Capreolus capreolus and muntjac Muntiacus reevesi, are rapidly expanding in distribution and possibly abundance, and may also reduce tree regeneration potential (Gill and Fuller 2007; Gill and Morgan 2010). Sheep farming on marginal land exerts strong grazing pressures in the wilder regions of England and Wales (Fuller and Gough 1999). Wild boar and beaver offer two services that the others in their guild (Fig. 16.4) do not: rooting and dam building. Rooting is important for creating bare ground patches for new vegetation to establish (Sandom et al. in prep-a) and dam building and the felling of riparian trees can be important for creating niche space for other species (Rosell et al. 2005). The former may be important for providing germination niches and the latter for creating standing deadwood.

\subsection{Rewilding Britain: wolves, wild boar, and beaver}

To help achieve our stated three goals of biodiversity, ecosystem services, and self-sustainability in Britain, we identify three processes in need of restoration which are provided by three native mammals that are either already being restored to Britain (beaver and wild 


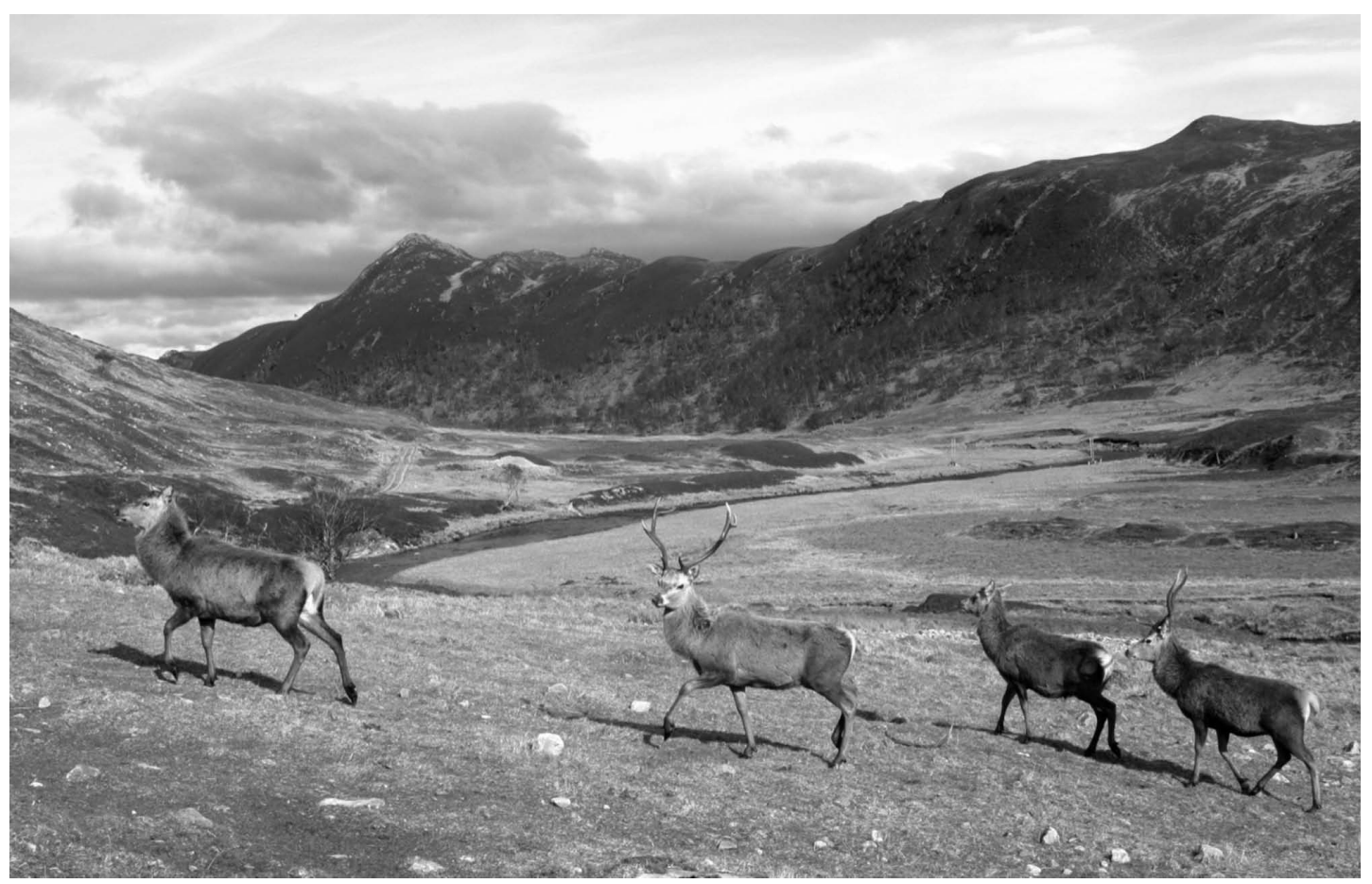

Figure 16.5 Alladale Wilderness Reserve with Red Deer Cervus elaphus. (C) C. Sandom.

boar), or are considered to be possible candidates in the future (wolf). Firstly, the imbalance between large herbivores and large predators is a significant limitation for any wild land in Britain to revert to a mosaic of vegetation communities. This is particularly true of the Scottish Highlands, arguably the wildest land in Britain, where high abundances of red deer, managed at high densities, are suppressing woodland regeneration and maintaining the landscape in a biodiversity poor state. In Wales and England there are fewer large deer, but instead the 'wild' lands in these countries are equally impacted by high densities of non-native farmed sheep and potentially other, smaller deer species. On this basis we diagnose predation as the top priority for restoration in the wild regions of Scotland, and the wolf as the key species to deliver this process. While sheep farming remains the dominant land use in the wild land of England and Wales, the rewilding of predation is unlikely to be achievable. Should farming in marginal areas be abandoned, as it currently is in continental Europe (Navarro and Pereira 2012), restoration of native, wild predator-prey interactions in core areas would be a possibility, with the lynx potentially a key species (see Box 16.1). After exploring the process of restoring predation and, with it, landscape-scale changes in woodland regeneration dynamics, we consider the important roles of rooting and dam building through restoration of wild boar and beaver populations. These species offer important processes for increasing ecosystem functionality.

\subsubsection{Rewilding and the land sharing versus sparing debate}

Before considering the restoration of these processes in detail, it must be decided where to focus rewilding efforts. An important and relevant debate to rewilding in Britain is consideration of the various merits of a land sharing or sparing approach to conservation². Twenty-six per cent of British land is protected (IUCN and UNEP-WCMC 2011). This compares favourably with, for example, the $12 \%$ cover of protected areas in the USA (IUCN and UNEP-WCMC 2011). However, the USA's $12 \%$ includes iconic national parks, such as Yellowstone, that are far closer to a naturally

${ }^{2}$ Land sharing (or wildlife friendly farming) 'which boosts densities of wild populations on farmland but may decrease agricultural yields' compared to sparing 'which minimizes demand for farmland by increasing yield' (Green et al. 2005). 


\section{Box 16.1 Reintroducing the lynx: a simple matter of choice?}

Radiocarbon-dated bones reveal that at least 12650 years ago lynx Lynx lynx occurred in Britain, and persisted here as recently as $1842-1550{ }^{14} \mathrm{C}$ yr BP (Hetherington et al. 2006). It was once believed that the downturn in their fortunes was prompted by climate change and thus loss of forest habitat between 10000 and 4000 years ago, but evidence of their historical persistence suggests they succumbed to persecution. There would be an argument under the EU Habitats Directive for reintroducing lynx to Britain, if people had played a hand in its demise. Furthermore, the condition that previous impediments to their survival have been reversed is certainly met in so far as nowadays, roe deer are so numerous, and still increasing, that they are commonly regarded as a pest. If lynx had the capacity to limit the current high populations of deer, that too could motivate their reintroduction. According to Hetherington (2005), neither is an especially compelling case, but recreating a large carnivore community could delight some (see Box 16.2), although it may be seen by others as foolish meddling. Hetherington et al. (2008) modelled the feasibility of such a reintroduction. They assumed lynx home range sizes characteristic of the Swiss Jura (females $45 \mathrm{~km}^{2}$, males $74 \mathrm{~km}^{2}$ encompassing female home ranges), and assessed the extent and connectivity of woodland in Scotland. This process identified $20678 \mathrm{~km}^{2}$ of potential habitat in 30 patches and two main networks of $15000 \mathrm{~km}^{2}$ in the Highlands, and $5330 \mathrm{~km}^{2}$ in the Southern Uplands, with an additional contiguous $810 \mathrm{~km}^{2}$ in England.

In Continental Europe, while lynx prefer roe deer, they will prey on ungulates up to the size of a red deer hind, taking also lagomorphs, small mammals, and ground-nesting birds (Breitenmoser et al. 2010). Hetherington et al. (2008) extrapolated from known population densities of deer in woodland to reach overall ungulate population densities in the Highlands and Southern Uplands comparable to those in the Swiss Jura, where lynx thrive. Then, using a relationship between lynx population density and log ungulate biomass/ $\mathrm{km}^{2}$, they estimated that the Highlands and the Southern
Uplands could sustain 2.63 and $0.83 \mathrm{lynx} / 100 \mathrm{~km}^{-2}$, respectively. This equates to 400 lynx in the Highlands and 50 in the Southern Uplands (including the Kielder Forest in England). A population viability analysis suggested such a Highland population would be viable, whereas the more southerly one might not.

What might be the pros and cons of such a reintroduction? Lynx kill sheep; for instance in Norway, where sheep are grazed in forests and roe deer density is low (Odden et al. 2006). In the Swiss Alps, $80 \%$ of farmers who lost livestock during the years 1979-1999 lost fewer than three and $95 \%$ of attacks were within $360 \mathrm{~m}$ of the forest edge (Stahl et al. 2001a; Stahl et al. 2002). Although the abundance of roe deer in Scotland might minimize depredation on sheep, there might also be some predation on grouse, and conservationists might fear for impacts upon capercaillies Tetrao urogallus, wildcats Felis silvestris, and pine martens Martes martes. Macdonald et al. (2013) conclude that this example illustrates the central importance of consumer choice in conservation. Lynx occurred in Scotland before, and conditions are now such that they could be there again. They could cause problems to some, delight to others. They would cause financial loss to some, while doubtless generating revenue for others (e.g. through ecotourism). As Macdonald et al. (2013) put it, 'it would surely not be beyond the wit of a nation such as Scotland to balance these costs and benefits with suitable economic instruments (e.g. compensation for loss of stock)'. The question is simply whether society wants lynx, and for those who think the answer should be yes, the road ahead lies in ordering their priorities and honing their advocacy. Again to quote Macdonald et al. (2013) 'The answer has some significance further afield because this is a case of a developed country considering the denizens of its own backyard; should the British public prove unenthusiastic about having lynx in its midst, this would not enhance the British conservationists' case that South Americans, Africans, and Asians should welcome, respectively, jaguars, lions, and tigers into theirs'. functioning ecosystem, containing a more complete trophic structure with the presence of top carnivores (Smith et al. 2003; and see Box 16.2), than any area in Britain (Fischer et al. 2008). While the US approach is land sparing, the British approach is perhaps best described as the sharing of spared land. For instance, in England, only $6.1 \%$ of the land is primarily protected for Nature under areas designated Special Sites of Scientific Interest (SSSIs). Importantly, this land is typically under management to sustain its biological significance and not governed by natural processes, while the large national parks and areas of outstanding natural beauty that are protected for multiple purposes cover $23.5 \%$ (Lawton et al. 2010). In spite of only $6.1 \%$ of land being spared for Nature in England, farming has become increasingly intensive elsewhere, which is linked to alarming wildlife declines over the last 50 years (Burns et al. 2013). 


\section{Box 16.2 Reintroducing swift foxes to agricultural landscapes}

Can carnivores ever be reintroduced to agricultural landscapes? The reintroduction of swift foxes Vulpes velox to Canada shows that indeed they can, while in Europe carnivores are currently naturally recolonizing agricultural land (Deinet et al. 2013). Swift foxes are meso-carnivores, and ecosystem functions had been heavily disturbed at trophic levels both above and below them in the Great Plains of North America, after Europeans had 'won the Wild West'. Lessons learnt from their reintroduction to North America highlight how new ecosystem processes offer both threats and opportunities to this functional group, and highlight the importance of adaptive management under altering ecosystem processes. Once, swift foxes were so abundant that over 117000 of their pelts were traded by just one of two Canadian trapping companies in a 24-year span of the late 1800s; by 1938 they were extinct in Canada. Reintroductions began in 1983, under the unpromising conditions of returning this native prairie specialist to a landscape where most of its former habitat had been ploughed, where keystone species like prairie dogs, bison, wolves, and grizzlies had been eradicated, and where a culture of killing carnivores was pre-eminent.

Nonetheless, lessons learned from our releases of 942 foxes over a 14-year period facilitated adaptive management (Moehrenschlager and Macdonald 2003). For example, the direct translocation of wild-caught foxes from the United States was more effective than the release of captive-bred foxes (Moehrenschlager and Macdonald 2003). Releases ended in 1997, and nowadays the steadily increasing Canadian swift fox population consists almost entirely of wild-born individuals that comprise a genetically diverse, structured population with increasing effective population size (Cullingham and Moehrenschlager 2013), leading to the species being downlisted nationally from 'endangered' to 'threatened' in 2012.

Remnant populations of imperilled species, or the early settlers following reintroduction, are not necessarily functional replications of larger indigenous populations. Swift foxes were returned to a landscape in which natural prairie had been changed to pasture, and the predatory guild up-ended. Human settlement fostered the invasion of red foxes, the slaughter of wolves released pressure on coyotes Canis latrans, and both of these beneficiaries of agriculture are morbidly inimical to swift foxes. However, this new terrain suited American badgers Taxidea taxus, whose burrows provided swift foxes with bolt holes to evade coyotes. Once swift foxes gained a foothold, their rapid reproductive rate allowed them to increase (Moehrenschlager et al. 2007). In a heavily degraded agricultural landscape, devoid of protected areas, the return of the swift fox to Canada could claim to be the most successful national-scale instance of carnivore reintroduction-and offers hope for rewilding and land sharing in the also entirely modified UK environment.
Considering this debate in the context of rewilding highlights the need to combine sparing and sharing to create a coordinated ecosystem-level approach to achieving our stated goals. Creating core areas is consistent with land sparing, while maintaining connectivity will require process-targeted rewilding in productive landscapes to achieve greater sharing with nature. Yet this is a simplistic representation, the real challenge will be striking the balance between nature and pressing human needs, primarily food production. Functioning nature is essential for delivering production, especially with regard to maintaining production capacity for future generations, but agricultural intensification has allowed increases in agricultural production that feed the growing human population and its demand for a better quality of life, which is currently synonymous with increased consumption. Careful consideration is required to balance current and future production requirements with responsible consumption, to ensure sufficient land sparing and sharing is possible to allow nature to function for the benefit of ourselves and biodiversity. It is not the purpose of this chapter to resolve this debate but, instead, to explore the potential to rewild both core areas and productive landscapes in Britain, and to set out what the potential opportunities and costs of doing so are in relation to our stated goals.

Using our three case study processes of predation, rooting, and dam building, delivered by three large mammals, wolves, wild boar, and beavers, we explore how they could rewild core areas and productive landscapes in Britain. We begin with predation and our wolf case study and the opportunities to create core areas in Britain. In our second and third case studies we explore wild boar and beavers returning to Britain in the context of land sharing. 


\subsubsection{Case study 1. Restoring predation through wolf reintroduction}

The wolf was formerly, globally, the most widely distributed non-commensal, terrestrial mammal (Mech and Boitani 2003). Persecution severely reduced its extent but, in recent years, it has enjoyed a comeback in Europe, having recently been seen in Belgium, Netherlands, and Denmark for the first time in at least a century (Deinet et al. 2013a). The notion of reintroducing wolves to Scotland has been a recurrent source of titillation amongst British conservationists for decades, most commonly with a view to limiting the numbers of red deer on the Island of Rum. But it also receives serious academic attention on the mainland, again in the context of deer control and the economics of sheep farming (Nilsen et al. 2007). Beyond the Scottish Highlands, wolves have not received serious attention in Britain. This is perhaps because, when considering the landscape scale, rewilding the Scottish Highlands is especially attractive with its low human population density, wide open spaces, and abundant deer populations.

Lessons learnt from the wolf reintroduction to Yellowstone National Park presage the cascade of good things awaiting Scotland with wolves-in Yellowstone, the red deer (known there, confusingly, as elk; but classified as Cervus elephas by the IUCN nonetheless) have declined and a changed landscape of fear ${ }^{3}$ has catalysed a trophic cascade that has increased riparian woodland, and with it, beavers, stabilizing the watercourses, reducing erosion, and increasing biodiversity (Ripple and Beschta 2012). In Scotland, heavy grazing by sheep or red deer (the latter maintained at high densities for stalking), prevents woodland regeneration and thwarts the recreation of a functioning Caledonian Forest ecosystem (Hobbs 2009). To judge by the models of Nilsen et al. (2007) and Manning et al. (2009), wolves would reduce red deer abundance by $50 \%$ and re-establish the landscape of fear to prompt a reconfiguring of the ecosystem. Yet, more than a decade ago we concluded that the release of free-ranging wolves in Britain, although an alluringly radical idea, was unlikely for as long as sheep farming remained a predominant land use (Macdonald et al. 2000). Nevertheless, we thought other marginally less radical possibilities existed, and foremost amongst them was a fenced wilderness area. Since that 2000 essay, entitled 'British mammals: is there a radical future?', and

3 Landscape of fear: 'altering foraging patterns and habitat use of herbivores under risk of predation' (Manning et al. 2009). the rewilding aspirations of Paul Lister, owner of the $90 \mathrm{~km}^{2}$ Alladale reserve, Scottish Highlands (Sandom et al. 2012; Fig. 16.6), we have sought to answer that question in two important ways. First, we explored whether an area of Scotland exists in which a suitably large fenced area might be feasible, biologically and geopolitically, and we modelled some consequences of varying its size in terms of the population dynamics therein of both the wolves and their likely main prey, red deer (see Fig. 16.5). Second, we addressed the question of how fencing a population of wolves might affect their capacity to exert top-down regulation on deer, thereby exposing an interesting paradox that might be relevant to all fenced reserves.

To reintroduce ecosystem function, both the species and the natural dynamics of the population must be restored (Bull et al. in prep) and, in the absence of a fence, predator killing outside unfenced protected areas can limit predator population density within. Source-sink population dynamics result from variability in habitat suitability within the meta-population. Importantly, even before population viability is threatened, the functionality of the population may be impacted (Bull et al. in prep). Wolves are commonly persecuted in most of their range in Europe (Linnell et al. 2008), and a reintroduction to Scotland without the use of a fenced reserve would almost certainly result in anthropogenic wolf mortality. It is expected that higher persecution would occur in unprotected compared to protected areas (Fritts and Carbyn 1995), although this is not always the case (e.g. Hilborn et al. 2006), which could create a source-sink population dynamic. Modelling suggests that, if $35 \%$ of dispersing wolves are lost from a protected area, wolves will possibly be prevented from achieving population densities sufficiently high to exert strong top-down forcing of the deer population (Bull et al. in prep). It should be noted that natural population dynamics may limit wolves' impact on deer density and is part of the totipotent state we seek to restore. If $>50 \%$ of dispersers are lost the whole population would be threatened. Hence, reintroducing wolves to a large fenced reserve in Scotland, as opposed to restoring nationally, could facilitate the restoration of predation as a process otherwise threatened by wolf killing.

Fences can pose a significant threat to wildlife, for instance, thousands of ungulates died in Botswana when they were cut off from essential water sources on their dry season migration, by a fence designed to prevent the spread of foot-and-mouth disease between wildlife and livestock (Hayward and Kerley 2009). Nonetheless, fencing game reserves in southern Africa 


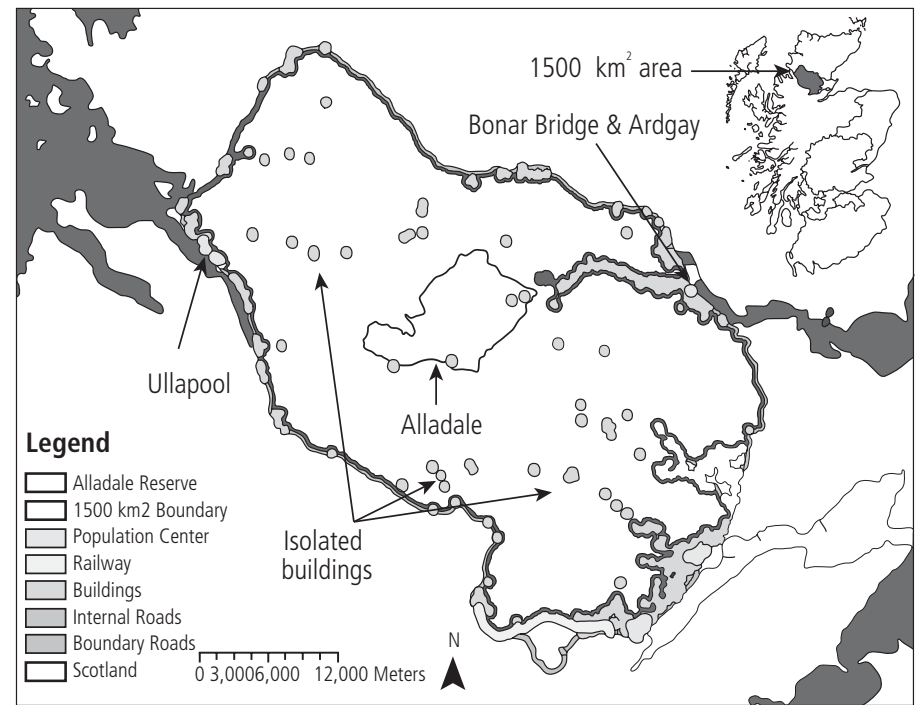

Figure 16.6 Method of calculating the maximum area of suitable land to be included within a fenced reserve. Tarmac road infrastructure and buildings $700 \mathrm{~m}$ from these roads were excluded creating a maximum boundary of $1500 \mathrm{~km}^{2}$. Buildings further than $700 \mathrm{~m}$ from tarmac roads were deemed potentially suitable for inclusion. Map in top right corner depicts the location of the $1500 \mathrm{~km}^{2}$ area in Scotland. Source Sandom et al. (2012). With kind permission from Springer Science and Business Media. is commonplace and helps to reduce human-wildlife conflict which, Hayward and Kerley (2009) argue, can conserve large mammals more successfully than in unfenced parts of East Africa. At the time of writing, a hotly debated correspondence has arisen over whether the least worst option for conserving African lions may be the fencing of their diminishing strongholds. Essentially, Packer et al. (2013) argue that fenced reserves offer better value than unfenced reserves and preserve predation as a process, while Creel et al. (2013) contest this conclusion, highlighting that as fenced reserves are typically small, they have low actual numbers of lions, despite the lion population densities being high. A landscape-scale fenced wilderness reserve in Scotland, based on the southern African model, would raise numerous ecological, economic, social, legal, and ethical questions (Deer Commission Scotland et al. 2004). For such a reserve to be realized, all of these aspects need to be addressed and challenging issues resolved; we explored three pertinent ecological and geographical questions: (1) how much space is required for a viable wolf population?, (2) will wolves limit deer numbers within a fenced reserve?, and (3) how much space is available around Alladale for such a reserve?

Tackling the issue of how much space is required is greatly aided by the intensive study of the wolves of Isle Royale, situated in Lake Superior in North America. Wolves have been present since they introduced themselves to the $544 \mathrm{~km}^{2}$ island in the late 1940s via an ice bridge (Mech 1966; Vucetich et al. 2012), illustrating that an area this size can feasibly sustain a small wolf population for at least 60 years. We used agentbased modelling to further this empirical example and revealed that a reserve of $600 \mathrm{~km}^{2}$ had an $88 \%$ chance of sustaining a wolf population after 100 years (Sandom et al. 2012), although our model did not take into account catastrophic events such as disease outbreaks, nor did we consider genetics. Disease would need to be treated and inbreeding managed, for instance through a managed metapopulation (Akçakaya et al. 2007). Isle Royale also reveals that genetic rescue of small populations should occur before the population becomes heavily inbred so as to avoid an immigrant dominating breeding opportunities and preventing improvements in population demographics. In 1997 an immigrant arrived on Isle Royale and within 2.5 generations was related to every individual in the population (Adams et al. 2011).

The scenario that recorded an $88 \%$ probability of a reserve sustaining a wolf population after 100 years also assumed that maximum pack density would not exceed one pack $/ 200 \mathrm{~km}^{2}$, a contentious assumption based on the intriguing population dynamics recorded on Isle Royale. Between 1959 and 1974 the wolf population appeared limited to around 17 to 31 animals in two packs (pack density of $1 / 272 \mathrm{~km}^{2}$ ). However, between 1975 and 1980 the population increased to 50 animals in five packs, a pack density of a little over one pack $/ 100 \mathrm{~km}^{2}$ (Peterson and Page 1988). At this density, the intermediate scenario in our modelling exercise, the probability of wolves persisting after 100 years in a $600 \mathrm{~km}^{2}$ reserve was just 24\% (Table 16.1). 
Table 16.1 Wolf extinction probability in the range of fenced reserve sizes $\left(200,600\right.$, and $\left.1200 \mathrm{~km}^{2}\right)$ modelled using each pack density scenario. Data are the number of repetitions with remaining wolves (out of a maximum of 50) in the given year from release. Under the limited and intermediate pack density scenarios pack density was limited at one pack $/ 200 \mathrm{~km}^{2}$ and one pack $/ 100 \mathrm{~km}^{2}$ respectively. Source Sandom et al. (2012). With kind permission from Springer Science and Business Media.

\begin{tabular}{|c|c|c|c|c|c|c|c|c|c|c|}
\hline \multirow[b]{2}{*}{ Reserve area $\left(\mathrm{km}^{2}\right)$} & & \multicolumn{3}{|c|}{$\begin{array}{l}\text { Unlimited pack } \\
\text { density scenario }\end{array}$} & \multicolumn{3}{|c|}{$\begin{array}{l}\text { Intermediate pack } \\
\text { density scenario }\end{array}$} & \multicolumn{3}{|c|}{$\begin{array}{l}\text { Limited pack } \\
\text { density scenario }\end{array}$} \\
\hline & & 200 & 600 & 1200 & 200 & 600 & 1200 & 200 & 600 & 1200 \\
\hline \multirow[t]{9}{*}{ No. of years after stocking } & 5 & 49 & 50 & 50 & 46 & 50 & 50 & 46 & 50 & 50 \\
\hline & 10 & 35 & 50 & 50 & 34 & 50 & 50 & 27 & 49 & 50 \\
\hline & 15 & 20 & 46 & 50 & 26 & 50 & 50 & 15 & 48 & 50 \\
\hline & 20 & 12 & 43 & 50 & 14 & 48 & 50 & 9 & 48 & 50 \\
\hline & 30 & 5 & 35 & 49 & 6 & 47 & 50 & 4 & 47 & 50 \\
\hline & 40 & 3 & 28 & 46 & 4 & 39 & 49 & 0 & 47 & 50 \\
\hline & 60 & 2 & 12 & 27 & 2 & 23 & 25 & 0 & 45 & 49 \\
\hline & 80 & 0 & 6 & 19 & 0 & 18 & 13 & 0 & 45 & 48 \\
\hline & 100 & 0 & 0 & 9 & 0 & 12 & 7 & 0 & 44 & 48 \\
\hline
\end{tabular}

On Isle Royale, when the pack density increased, the wolf density also increased from 57 wolves $/ 1000 \mathrm{~km}^{2}$ to 92 wolves $/ 1000 \mathrm{~km}^{2}$. In our modelling scenarios we contrasted a limited pack density scenario (one pack $/ 200 \mathrm{~km}^{2}$ ), and an unlimited pack density scenario. Under the limited scenario the average maximum wolf density was just 48 wolves $/ 1000 \mathrm{~km}^{2}$ compared to the unlimited scenario of 104 wolves $/ 1000 \mathrm{~km}^{2}$, and compares well with Isle Royale.

The implications of these maximum densities were dramatic, with the limited scenario having a very minor impact on deer population density $\left(>20 / \mathrm{km}^{2}\right)$ compared to the unlimited scenario where deer population densities were typically reduced to $\sim 4 / \mathrm{km}^{2}$ (Fig. 16.7). This dramatic reduction in prey population density caused, in turn, dramatic declines in wolf survival and ultimately is the likely cause of their extinction in most modelled instances. On Isle Royale, the wolves' primary prey species is moose Alces americana and, while the overall impact of top-down forcing on the population is unclear, the moose population did fall during the period of high wolf population densities (Vucetich and Peterson 2004). The wolf population crashed in the early 1980s as a result of starvation, intraspecific competition, and disease (Peterson and Page 1988; Peterson et al. 1998). Our modelling may over-estimate the risk of extinction associated with prey decline, as our model only includes a single prey species. A greater variety of prey, such as sika and roe deer, wild boar, and beaver, could allow for wolves to switch prey species when red deer become scarce, increasing their chances of survival.
In summary, the empirical and modelling evidence suggests that a fenced area of at least $544 \mathrm{~km}^{2}$ offers the possibility of a 'viable' population ${ }^{4}$ and a top-down effect on deer density. Such a reserve would provide a unique rewilded area in Britain and would offer the opportunity for novel scientific insight, but would have to be managed to avoid undesirable extremes and inbreeding that threaten small populations. Such experiments could prove invaluable in delivering a rewilded Britain.

So, is such a landscape-scale fenced reserve conceptually possible in Scotland? A GIS exploration of the area surrounding Alladale suggests that the limited infrastructure in the region could allow for a reserve of $\sim 1500 \mathrm{~km}^{2}$ without affecting any tarmac roads or railway lines and only incorporate 35 isolated buildings or small clusters of buildings (Fig. 16.6). The suitability of the land within this area varies according to a number of variables, including habitat, buildings, agriculture, other leisure uses, and Sites of Special Scientific Interest (SSSI). The majority of the area indicates a neutral or positive suitability for such a reserve with areas of high ground presenting the greatest difficulties as they are especially valued by hill walkers; fences limit the ease of access, restricting people's right to roam. A further consideration is that the introduction of keystone species would have unknown impacts on SSSIs and

\footnotetext{
${ }^{4}$ Here, we define wolf viability in the context of a monitored and managed population within a fenced reserve over the medium term; this is not applicable to unfenced, longterm scenarios.
} 

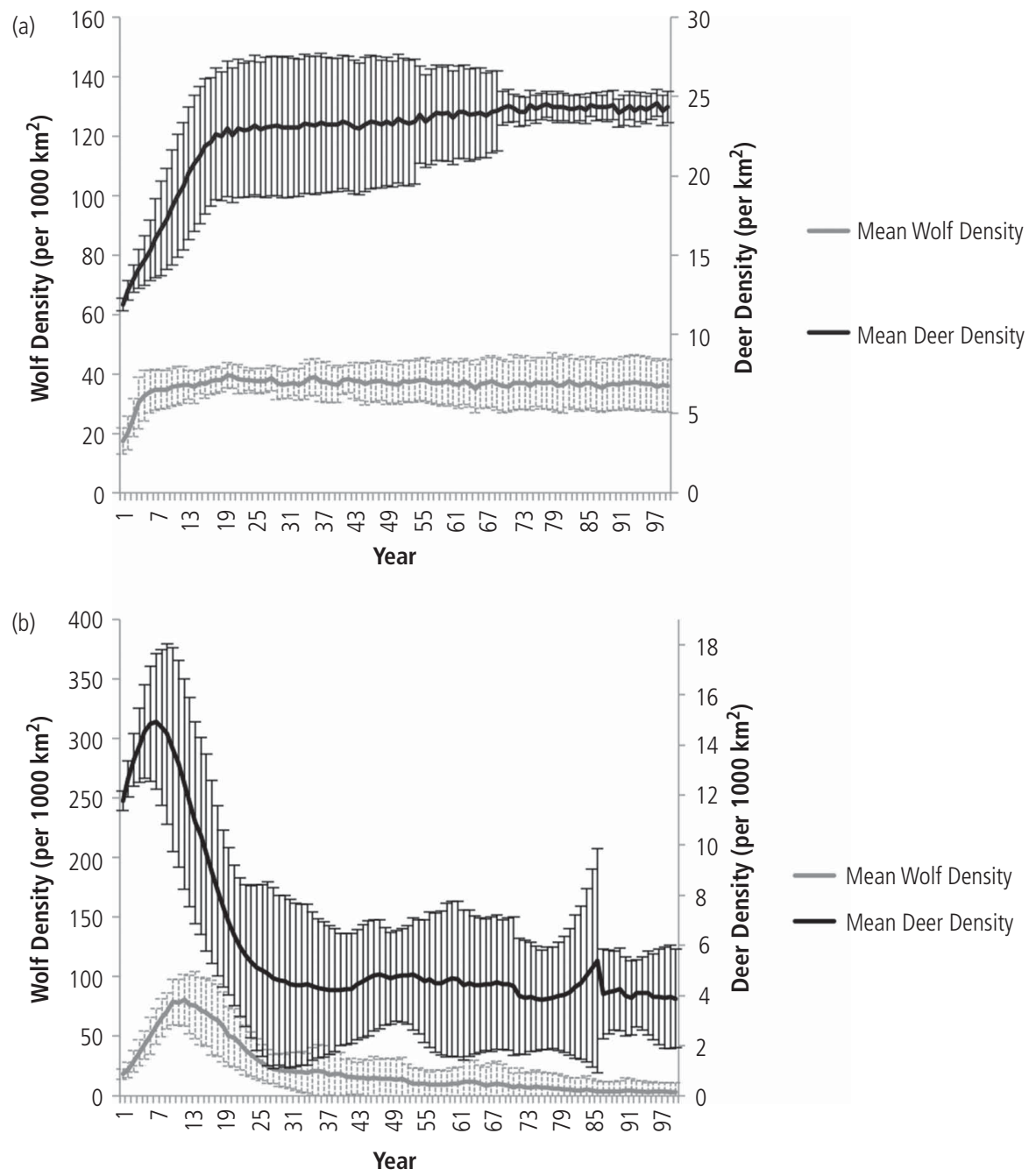

Figure 16.7 Average deer and wolf population densities in the $1200 \mathrm{~km}^{2}$ reserve. Simulations were excluded from analysis of the deer population from the point wolf extinction was recorded; data are the mean and standard deviations. (a) Modelled results under the limited pack density scenario. (b) Modelled results under the unlimited pack density scenario. Source Sandom et al. (2012). With kind permission from Springer Science and Business Media.

may be considered a threat. In spite of largely encouraging projections, any such reserve would have implications for the local community, and the costs and benefits would need to be considered carefully, as well as the legal implications of housing both predator and prey (Sandom et al. 2012).

The low population density and high deer density make the Scottish Highlands an obvious area of interest for considering a fenced reserve with large predators, and England and Wales could easily be ignored and assumed to be unsuitable. This is a particularly pertinent issue, with the reported expansion of large predators across western Europe (Deinet et al. 2013b). For instance, initial signs indicate that wolves are being welcomed back to Denmark since they arrived in 2012 (Miljominsteriet Naturstyrelsen 2013). An active reintroduction is quite different from a natural recolonization, but the question 'Is there really no room for large predators in England and Wales?' can reasonably be posed. National Parks are often important examples of a country's natural ecosystem. In England and Wales they are perhaps the finest examples of cultural 
rural landscapes. There are ten National Parks in England, covering $9.3 \%$ of the land area and three National Parks in Wales, covering $19.9 \%$ of the land (National Parks UK 2012). The largest National Park in England is the Lake District at $2292 \mathrm{~km}^{2}$, favourable compared to our Scottish example above. However, over 40000 people live in the National Park and, whereas deer are abundant in Scotland, there are sheep in the Lake District, which is already a cultural icon and receives in the region of 14.8 million visitors a year, spending as much as $£ 994$ million during their visits (National Parks UK 2012). In contrast, Northumberland National Park, for example, covers $1048 \mathrm{~km}^{2}$, has 2500 people living in it, and is visited by 1.5 million people a year, spending a total of $£ 190$ million (National Parks UK 2012). It is primarily covered by farmed moorland and perhaps bears some similiarity to our Scottish case study, although deer densities are likely to be lower and sheep densities higher. With the decoupling of Common Agricultural Policy (CAP) subsidy payments from production and the potential for further change, there may be increasing concern that farming marginal land will become unsustainable or undesirable (Acs et al. 2010).

As a consequence, the local community may wish to be presented with alternatives for supporting the rural economy. This is a problem that is already advanced in continental Europe with what has been termed rural land abandonment (Navarro and Pereira 2012). In some instances, communities in these regions have turned to wildlife tourism as an alternative income. Charismatic large mammals are a significant draw. Staffan Widstrand, from Rewilding Europe, who has considerable experience in the wildlife tourism trade, suggests that high quality viewing opportunities of charasmatic animals can be charged at between $€ 120-270$, to see bears in Finland, and €200, to see wolves howling in Sweden (Widstrand 2013). In Sierra de la Culebra in Spain, the wolf is being seen as a new economic opportunity for the tourist industry (Richardson 2013). Further afield, the wolf reintroduction to Yellowstone National Park in 1995 was associated with a 35.5 million dollar increase in visitor spending in the local economy (Duffield et al. 2008). Rewilding a National Park in Britain is no doubt a radical and controversial proposal but, based on experiences elsewhere, one that may warrant further consideration for its financial opportunities as well as its environmental benefits. However, we want to emphasize we are proposing the exploration of the concept, an assessment of risk and opportunity, proceeding any further could only be achieved with local enthusiasm and leadership.
The predation case study has focused around the uplands where the human population density is lower. National Parks also exist in the lowlands and could also be considered as rewilding core areas. The South Downs National Park, for example, is $1624 \mathrm{~km}^{2}$ and so relatively large, but with 120000 people living in the park and the land primarily being productively farmed, a wolf reintroduction is highly unlikely. However, another large mammal, the wild boar, has been establishing itself in lowland Britain and can perhaps be accommodated, as explored in the following case study.

\subsubsection{Case study 2. Restoring ground disturbance through wild boar reintroduction}

Wild boar were eradicated in Britain at least 300 years ago, through habitat loss and over-hunting (Yalden 1999), a decline from perhaps as many as 950000 animals during the Mesolithic (Maroo and Yalden 2000). Their current status is not clear, as it has been a moot point whether or not they have been reintroduced! In the late 1980s, escapees from farms took pre-emptive initiative and bypassed the smouldering debate as to whether it would be desirable to reintroduce boar to the UK.

At $\sim 100 \mathrm{~kg}$, wild boar were the largest member of the rooting guild, which also includes the badger, in the UK ${ }^{5}$. Rooting is an ecological trade, whose practitioners disturb ground vegetation and top soil while foraging, thereby creating ecosystem upheaval in ways that have major effects, akin to ploughing, on plants and all that live thereon. From an ecologist's perspective, the reintroduction debate has centred on this role of ground disturbance as a vital process within naturally functioning ecosystems; a process that creates niche opportunities for less robust plant species to survive in communities otherwise dominated by more competitive plants (Hobbs and Huenneke 1992). From the hunter's perspective, wild boar represent an interesting and potentially profitable quarry. Others, especially those with experience of the agricultural ravages caused by boar on continental Europe or mindful of their potential as disease vectors, view the prospect of

\footnotetext{
5 The 'purity' of wild boar is difficult to assess. Wild boar can be crossed with domestic pig breeds, typically to increase litter size and so yields. Genetic tests are not available as standard samples for wild boar are unavailable. Certain morphological characteristics are thought to be indicative of wild boar rather than hybrids, including: straight head profile, body weight held over front legs, straight tail, and entirely black muzzle (Goulding 2014).
} 
their reintroduction with disdain. As always, there is a question of balance-as a returning native species, wild boar would restore a missing link in Britain's temperate ecosystem and, less tangibly, would fill a void in the naturalist's sense of Nature's wholeness, but in the absence of predators and other ecosystem changes in the last 300 years they could become a pest, and potentially a bad one ${ }^{6}$. So where, and how, should that balance be struck?

Considering the then lively debate on invasive species, the attention being brought to bear on every detail of a proposed beaver reintroduction (see Case study 3), and the polarized views on boar in particular, Macdonald and Tattersall (2001) wryly noted the deafening silence from government (Defra) on the escaped boar. During the early years of a back-door recolonization, it might have been nipped in the bud. Thirty years later, there are established populations in Kent/Sussex ( 200 animals, estimates from 2004), the Forest of Dean (probably $>100$ ), and Dorset $(<50)$ (Defra 2008). Three populations of wild boar apparently flourish in Scotland (Campbell and Hartley 2010). With the passage of time, and of reports (e.g. Goulding et al. 1998), Defra has left the decision of whether or not to tolerate wild boars in the wild to individual land owners (Defra 2008).

Against this background we tackle two families of questions, remembering that wild boar are primarily a woodland species and that woodland is nowadays both limited and fragmented in Britain (see Chapter 12 , this volume). First, at a landscape scale, and in the long run, can wild boar live free in the modern British countryside? Second, with rewilding in mind, how can their role in the processes of ecosystem functioning be fine-tuned to strike a balance between pest and asset of which society will approve? Boar are evidently viable in southern England and we already know from Leaper et al.'s (1999) calculations that there is sufficient suitable woodland in Scotland to support a minimum viable population. We will return to this landscapescale question below, but first we focus at the level of the individual, as we answer questions about exactly how wild boar forage and how suitable this foraging

\footnotetext{
${ }^{6}$ For example, in Luxembourg 13276 incidences of crop damage by wild boar were reported between 1997 and 2006, costing 5.27 million euros and covering 3900 ha. The annual area affected was approximately $0.31 \%$ of agricultural land (Schley et al. 2008). Disease is also a considerable concern. For example in the 1990s, Germany recorded 424 outbreaks of classical swine fever in domestic pigs. Of the recorded primary outbreaks, 59\% were associated with direct or indirect contact with infected wild boar (Fritzemeier et al. 2000).
}

is to introduce naturalistic or rewilded disturbance regimes. In our example, we focus on this process in the Scottish Highlands, but our studies of wild boar behaviour have wider relevance, not only insofar as wild boar behaviour affects their impact in the ecosystem, but more immediately because such studies are a step towards answering a manifestly practical question: can heavily managed, fenced, wild boar be used cost-effectively within a conservation management system to foster desirable habitats? ${ }^{7}$ A specific instance of this question focuses on bracken Pteridium aquilinum, a native to the UK, but one that is both problematic to conservationists and to stockmen, and is expanding (Robinson 2009).

So, can wild boar be employed as rewilding engineers, and specifically create niches of opportunity for less competitive species within bracken and heather dominated communities? We tackled this in a series of experiments, within a 125 ha fenced area at the Alladale Wilderness Reserve (Fig. 16.1). There, we asked: (a) at what rate do wild boar root?, (b) do wild boar use a foraging strategy that makes them effective ecosystem engineers?, and (c) can wild boar promote woodland regeneration and disturb bracken and heather communities in the Scottish Highlands?

To achieve this, eleven $\sim 0.5$ ha enclosures were established on heather moorland and stocked for at least nine weeks with varying densities of boar (between 4.5 and 14.6 boar/ha). The accumulation of rooted area was measured weekly and revealed a median per capita rooting rate of $42.4 \mathrm{~m}^{2} /$ week; higher rates later in the study period were probably due to high rainfall making rooting easier (Sandom et al. 2013d; Fig. 16.8). At natural population densities (unlikely to exceed $4 / \mathrm{km}^{2}$ ) the rooting is estimated to cover less than this, at around $15600 \mathrm{~m}^{2} / \mathrm{km}^{2} /$ year (Sandom et al. 2013b).

Rooting behaviour is part of the wild boar's overall foraging strategy and targeted to exploit specific resources. To explore whether wild boar have a foraging strategy that can promote woodland expansion, beneath-canopy seedling regeneration, and/ or bracken disturbance, six GPS collared wild boar were monitored intensively over a 12-month period within the 125 ha enclosure, consisting of remnant Caledonian pine woodland, broadleaved woodland, and open heather moorland (Sandom et al. 2013c).

\footnotetext{
7 The cost-effectiveness of using naturalistic disturbance is unclear, with research indicating costs range between $£ 184$ and $£ 1961$, depending on stocking density and the rate of rooting, with only the lower end of this scale being competitive, although other business models could be more effective (Sandom et al. 2013d).
} 


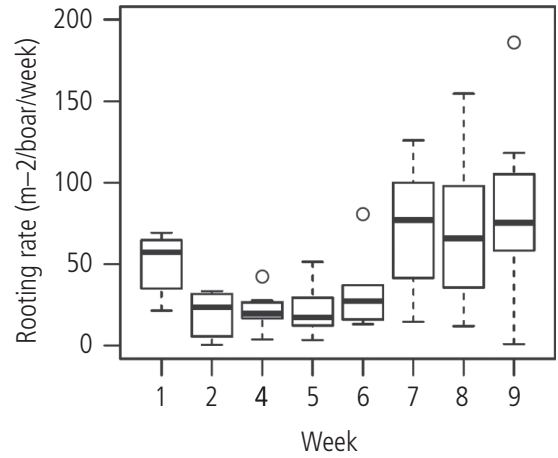

Figure 16.8 Median per capita rooting rates plotted per week (median $\pm I Q R, n=9$ ). Source Sandom et al. (2013d). Reproduced with permission from John Wiley \& Sons.

The ground vegetation was a mixture of bracken $(7 \%)$, heather $(65 \%)$, and grass communities (26\%). The boar were particularly industrious during the autumn and winter, spending $\sim 80 \%$ of their active period foraging (Fig. 16.9) and, while they were active for longer periods (14 hours) during the long summer days of northern Scotland, they spent the longest period rooting during the autumn and winter (9-9.9 hours/day). Significantly, the boar preferred a woodland canopy and favoured bracken communities while rooting in the autumn and winter, and grass communities while grazing ( $28 \%$ of the active period) in the spring and summer (Sandom et al. 2013c).

At the point of impact, rooting considerably reduces vegetation biomass and species richness, and they are capable of creating relatively large patches of bare ground (within the 125 ha enclosure, 168 deep rooted patches $>1 \mathrm{~m}^{2}$ were created after 21 months of boar activity, the average rooted area was $78 \mathrm{~m}^{2}$ and covered a total area of $13143 \mathrm{~m}^{2}, 1.05 \%$ of the enclosure, although the boar were stocked at higher than natural densities; Sandom et al. in prep-a). However, the lasting effects of rooting are dependent on the vegetation community. Rooting is typically characterized as deep (sustained rooting in a specific area that disturbed the soil layer) or shallow (surface vegetation disturbed without disturbing the soil layer); deep rooting was employed by the boar in bracken areas to exploit the rhizome network, typically found $5-15 \mathrm{~cm}$ below the surface.

Twenty $2 \times 2 \mathrm{~m}$ fenced exclosures were established, half in rooted and half in unrooted bracken areas, to prevent further disturbance, and were monitored over two years. The differences between these areas were dramatic, with a $64 \%$ reduction in bracken frond density in the following spring compared with unrooted areas. Two years post rooting, graminoids (grasses, sedges, and rushes) had $14 \%$ greater coverage in rooted areas. Forb species richness was one and two species greater in the first and second years post rooting, respectively. Bracken was, however, observed to re-establish in most, but not all, rooted areas in subsequent years after the two-year monitoring period (Sandom, personal observation). In comparison, shrubs within heather-dominated communities were greatly reduced ( $>40 \%$ cover to $<15 \%$ ) and slow to recover two years post-rooting $(<20 \%)$, while grasses had increased in coverage two years post rooting $(\sim 40 \%)$ compared to pre rooting $(<40 \%)$ and being reduced to $\sim 10 \%$ cover in the first year post rooting. Rooting also stimulated the germination of seedlings, although at the expense of more established saplings that were often bark stripped or uprooted. Seedling regeneration was recorded in $40 \%$ of the rooted areas in the 125 ha enclosure, although the greatest regeneration occurred beneath broadleaved and mixed woodland stands. In a comparison of regeneration between quadrats in rooted and unrooted areas, 30\% more quadrats in rooted areas had regeneration.

This series of experiments suggests that the boar could be a good tool, both to break the dominance of bracken and heather, and indeed hasten woodland regeneration beneath an established canopy, whether in a core area or a productive landscape. Insofar as boar support woodland regeneration, in a full life-cycle analysis they can claim some of the credit for associated ecosystem services such as water regulation, carbon sequestration, and recreation (National Ecosystem Service Assessment 2011b). There are, however, downsides: with their broad diet of over 400 species (Schley and Roper 2003), at high population densities the boar could damage rare species and crops. So, regarding the polarized debate as to whether to allow them back into Britain, the pros and cons of boar depend critically on the circumstances. It is certain that some individual boars will be in conflict with people and, because there is no predatory check on their numbers in the modern resource-rich landscape and they will outgrow the resources that society will feel comfortable sharing with them, it is also certain that sooner or later boar will be in conflict with many people. Indeed, on continental Europe there are reports of wild boar attacking people (Kotulski and König 2008), and where populations are present in Great Britain there are regular reports of them uprooting parks, gardens, and golf courses (Sims 2005; British Wild Boar 2015). At both scales, this is probably easily, indeed profitably, solved: the nuisance individuals, and indeed a percentage of the whole 

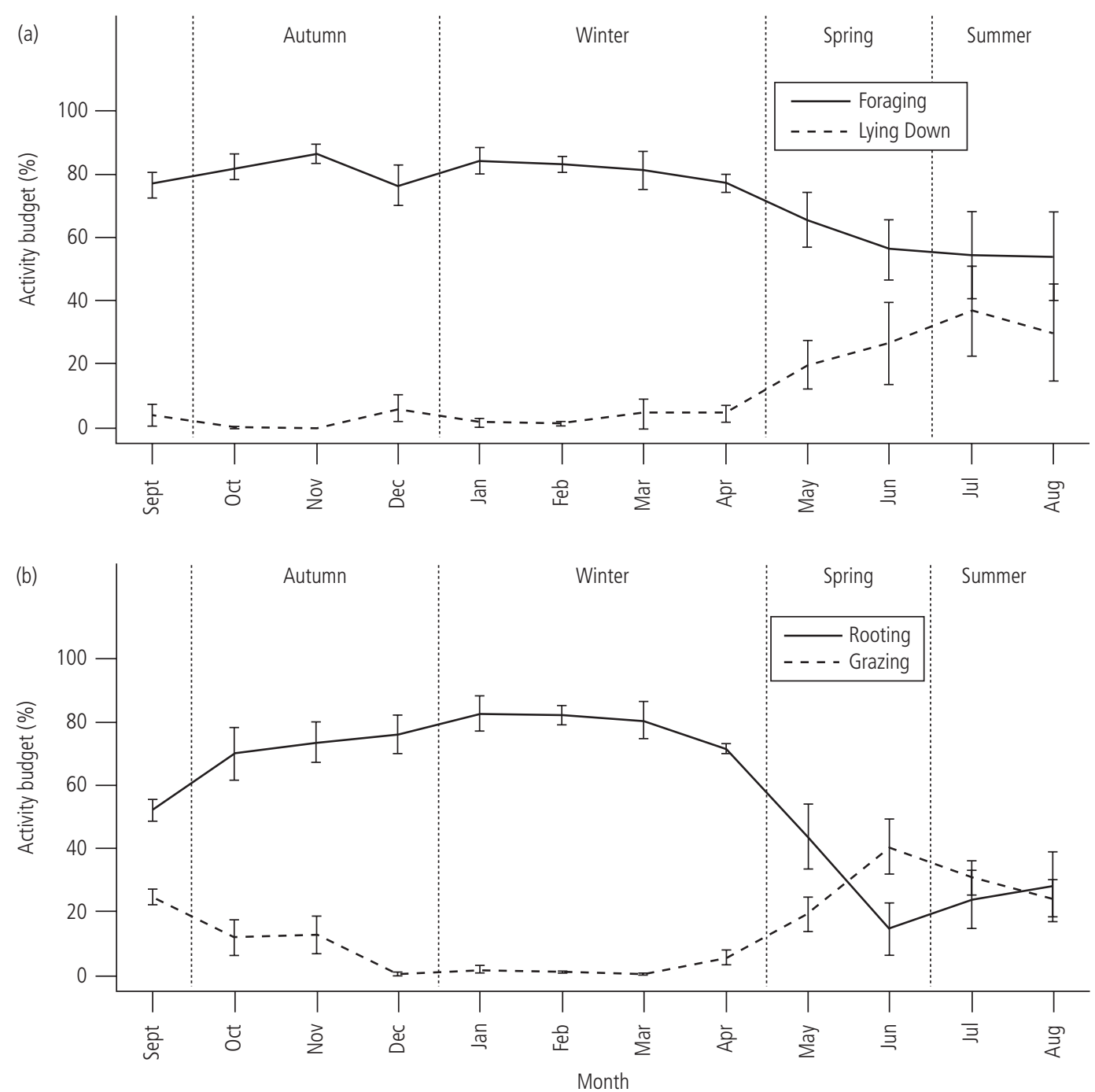

Figure 16.9 (a) Monthly variation in activity budget of lying down versus foraging ( $n=4$, mean, SE). (b) Monthly variation in foraging activity budget of grazing and rooting behaviour (mean $\pm S E, n=4$ ). Source Sandom et al. (2013c). Reproduced with permission from John Wiley \& Sons.

population, can be shot. That boar were over-hunted to extinction before, suggests that they could be limited to acceptable numbers, if society formed a view on what numbers were acceptable.

Perhaps surprisingly, people and wild boar are already sharing productive landscapes in Britain. There are benefits associated with increasing woodland diversity and in the long term they are likely to be a key element in allowing wooded ecosystems to be self-sustaining and biodiverse. But while some enjoy their presence, whether for viewing or hunting, the potential for conflict is considerable. Thus they would be a key component in a core area. In productive landscape predatory control, through humans, it is likely to be necessary to ensure that the balance between biodiversity and productivity is achieved.

\subsubsection{Case study 3. Restoring river channel and riparian disturbance by reintroducing beaver}

Beavers are ecosystem engineers in the most literal sense. They have a marked influence on their environment and on other wildlife due to their river damming 
and tree-felling activities (Rosell et al. 2005), qualifying them as keystone species ${ }^{8}$ (Power et al. 1996). But the sounds of their industry have lain dormant since their demise here in Britain: by 1191, Geraldus Cambrensis ${ }^{9}$ reported that the Teivi was the only river in Wales, or even in England, where beavers remained, and Kitchener and Conroy (1997) record their disappearance from Scotland 400 years ago. Today, however, along the shores of the lochs of Knapdale Forest ${ }^{10}$ you can again hear the warning slaps of their paddlelike tails on the water, and see the chiselled stumps of their arboriculture as you squelch through their ponds-and it is a thrill that touches the naturalist's soul. The Knapdale beavers (currently three breeding pairs, and two single adults ${ }^{11}$ translocated from Norway in 2009/2010 (and see Box 16.3), and at least three Scottish-born young, R. Campbell-Palmer pers. comm.) are part of an experiment ${ }^{12}$ choreographed by Scottish Natural Heritage (government), implemented by the Scottish Wildlife Trust and the Royal Zoological Society of Scotland (non-government), in which their lives (deaths, births, health, movements, habitat use, and foraging) are monitored comprehensively (WildCRU is one of a number of scientific auditors ${ }^{13}$ ). Mind you, it is scarcely less thrilling to see the entirely illegal immigrant beavers of Tayside, where several escapees from captivity, or possibly renegade releases from as early as 2001, have now spawned over 100 wild-living

\footnotetext{
8 A keystone species is 'one whose impact on its community or ecosystem is large, and disproportionately large relative to its abundance.' Power et al. (1996).

${ }^{9}$ Geraldus Cambrensis describes how beavers, 'in order to construct their castles in the middle of rivers, make use of the animals of their own species instead of carts, who, by a wonderful mode of carnage, convey the timber from the woods to the rivers. Some of them, obeying the dictates of Nature, receive on their bellies the logs of wood cut off by their associates, which they hold tight with their feet, and thus with transverse pieces placed in their mouths, are drawn along backwards, with their cargo, by other beavers, who fasten themselves with their teeth to the raft.'

10 Loch Coille-Bharr and its satellite, Dubh Loch (the exit of which has been beautifully dammed), Un-named (S) Loch (also known as Lily Loch), Lochan Buic, Loch Linne, Loch Fidhle, Loch na Creige Mòire (Creagmhor) and Lochan Beag all have, or had, beavers released.

11 Four pairs, and one sub-adult believed now to be breeding and to have replaced her mother in the breeding pair; these nine animals are those that are known to have survived and remained within the release site of the 16 animals originally released (Harrington et al. 2013).

12 The Scottish Beaver Trial-<http:/ / www.scottishbeavers. org.uk/>.

${ }^{13}$ Full details, and all cited reports, available at: <http:/ / www.snh.gov.uk>.
}

descendents (Campbell et al. 2012a) ${ }^{14}$. Whilst the Scottish Government has yet to decide on the long-term future of beavers in Scotland ${ }^{15}$, for now beavers are back in Scotland and the first steps to rewilding Britain are underway! ${ }^{16}$ The history of their official return has been a riveting bio-political challenge, no less interesting than the biological challenge faced by the beavers in rebuilding an ecosystem (Hodder et al. 2009). Somewhere near the beginning of the saga, and over a decade before the first beavers were actually released in the wild, Macdonald et al. (1995) set out the terms of the debate in a paper entitled: Reintroducing the European beaver to Britain: Nostalgic meddling or restoring biodiversity? The debate involved intersecting biological and management considerations: biologically, there were questions about whether the beaver's absence had resulted in their niche being lost irretrievably; whereas in management terms, opinion was polarized over whether the habitat creation and ecological services rendered by returnee beavers would, or would not, outweigh their potential for pestilence.

What is this ecosystem service that beavers deliver, which makes them more than just another notch in the tally of species diversity? It is that they are unusual, indeed as a family unique, in their ability to dam watercourses, creating home-made habitat through treefelling, and dam and lodge building to engineer lakes and wetlands (although Eurasian beavers are said to dam less than their Canadian cousins, this may be more to do with differences between the landscapes than between the species; Campbell et al. 2012a). These activities cause river corridors to become wider, geomorphologically more complex (Westbrook et al. 2011), biologically more diverse, and more productive (Rosell et al. 2005). Of course, this means things change; for instance, dam construction creates ponds that will alter the freshwater insect assemblage from running water species to a pond community, this may reduce local species richness (alpha diversity ${ }^{17}$ ), while increasing

14 In March 2012, the Scottish Minister for the Environment announced that beavers in Tayside would be tolerated until a decision on the future direction of beaver reintroduction in Scotland is made in 2015. Monitoring is being carried out by the Tayside Beaver Study Group, <http:/ / taysidebeaverstudygroup.org.uk/>.

15 A formal decision will be made by the Scottish Government in 2015, on the basis of the outcomes of the Scottish Beaver Trial at Knapdale, in conjunction with findings from the monitoring of the unlicensed Tayside beaver population.

16 The beaver reintroduction trial at Knapdale, Argyll, is the first formal reintroduction of a mammal to Britain.

17 Alpha diversity: biodiversity within a particular site, community, or ecosystem; usually expressed as the species richness of the site. 
biodiversity at the landscape or regional scale (gamma diversity ${ }^{18}$ ) (Rosell et al. 2005). Furthermore, at a catchment scale they are responsible for filtering sediment from water that seeps through the dams, creating wetlands (Wright et al. 2002) (a habitat disappearing in many parts of Europe) that tend to be a particularly rich environment for Nature (Pollock et al. 1998), and creating a mosaic landscape which, through the eyes of some beholders, is beautiful (Rolauffs et al. 2001; Müller-Schwarze and Sun 2003).

Ecosystem services are often classified as regulatory, supporting, or cultural. In this case, beavers provide all three (Müller-Schwarze and Sun 2003; Rosell et al. 2005): (a) regulatory services: improved water quality, flooding prevention, water flow regulation, raising the water table, and the conservation of water; (b) supporting services: creating and maintaining wetland habitats with benefits for biodiversity, including benefiting some economically important fish species by raising the water temperature (this effect can however become detrimental to the fish if the temperature rises too high and reduces dissolved oxygen content); and (c) cultural services, such as tourism and aesthetics (Macdonald et al. 1995; Tattersall and Macdonald 1995; Collen and Gibson 2000; Campbell et al. 2007).

Who would choose to forego these benefits? Plenty of people, and particularly those looking at damage done by a different species, the American beaver Castor canadensis (Harkonen 1999; Jonker et al. 2006): not least in Tierra del Fuego where it is regarded as a toxic invasive, introduced into a landscape where many trees have not co-evolved to regenerate when felled (Skewes et al. 2006; Anderson et al. 2009). The flooding of gardens and drains, the felling of orchards and deflection of streams annoy people. Others see the beautiful beaver ponds as breeding grounds for mosquitos (Butts 2001) and giardia (Rosell et al. 2001). In the UK, salmon fishermen feared their sport would be damaged, and were unmoved by the assurances of Norwegian fisherman who tended to see beavers as an asset (Collen and Gibson 2000). The Scottish Government through Scottish Natural Heritage has established a BeaverSalmonid Working Group to report on issues relating to the potential impacts, positive and negative, of beavers on salmonids - this will report in 2015.

Thus far, beaver-induced hydrological changes at Knapdale have been less than expected, with little damming activity taking place (Jones et al. 2013) (with the notable exception of a dam built on a drainage

\footnotetext{
18 Gamma diversity: total species richness over a large area or region.
}

ditch between Loch Coille Bharr and Dubh Loch, impounding a significant amount of water and effectively increasing the size of the Dubh Loch almost 5-fold, R. Campbell-Palmer, pers. comm.). Habitat use and foraging activity (four-years post-release at the time of writing) has largely been restricted to the original release points (Harrington et al. 2013), with some localized impacts on woody vegetation (Moore et al. 2013) and aquatic vegetation (Willby et al. 2011), although it is premature to draw firm conclusions on the impacts (either positive or negative) of beavers at Knapdale.

In the more human-dominated landscape of the Tayside river catchment, Campbell et al. (2012a) similarly found beaver damming and crop foraging to be minimal (only three beaver groups of an estimated 38-39 groups, had built dams, and only two groups foraged in crops). Conflict with landowners in the Tay catchment was therefore highly localized (even after several years of beaver presence ${ }^{19}$, and farmers (that did not have dams on their land) and fishermen seemed unconcerned with the presence of beavers (although gillies $^{20}$ expressed some concern about fallen trees in the water snagging fishing lines; Campbell et al. 2012a). The threat to agricultural crops can be contained-or mitigated-by the establishment of a riparian buffer strip, because beavers usually forage within $<40 \mathrm{~m}$ of a watercourse (Campbell et al. 2012a). In Norway, Macdonald et al. (1995) reported that a Forest Owner's Association concluded that beaver damage was so minimal it was inappropriate to insure against.

Led meticulously by the UK's statutory conservation agencies, all these pros and cons, and the questions of balance between them are being exhaustively reviewed (e.g. Harrington et al. 2012; Moran and Hanley-Nickolls 2012; Moore et al. 2013/ see <http:/ / Scottishwildbeavers.org $>$ ). In summary, there are functional traits (Luck et al. 2009) brought by beavers (dam building and tree felling), to be offset against threats that they pose to provisioning services (agriculture and forestry) and, ultimately, the balance sheet of these factors will determine the beaver's immediate future in Scotland. Should they remain, their natural expansion from their starting locations in Knapdale and the

19 Although Halley and Rosell (2002) note that across Europe, marginal areas that cannot sustain permanent beaver occupation tend to be those that require most beaver engineering in the form of dam construction and felling of large trees, and thus are the source of most conflict between beavers and humans-and, therefore, conflict may increase as beavers spread further across Scotland.

20 According to the Oxford English Dictionary, a gillie is 'a man or boy who attends someone on a hunting or fishing expedition.' 


\section{Box 16.3 Beavers' response to environmental variability}

To plan successful rewilding projects, it is necessary to learn as much as possible about beavers in the wild in order to determine how they might behave in the UK. To do so, we turned to Frank Rosell's (Telemark University) pioneering long-term project in Norway. There, while we were disappointed not to repeat the early observations of beaver behaviour reported by Juvenal-'Qui se Eunuchum ipse facit, cupiens evadere damno Testiculi'21 —we did see a brand new beaver behaviour, tool-using (Thomsen et al. 2007), and we revealed the importance to their population dynamics of environmental variability, a factor increasingly recognized by ecologists as widely important to mammalian populations (amongst our own WildCRU work, see Campbell et al. 2012b; Campbell et al. 2013; Zhou et al. 2013).

Our study site was centred on three large rivers, the Straumen, the Gvarv, and the Sauar, in Telemark, southern Norway (Campbell et al. 2012b). Here we examined trends, from over 90 years of data, in different components of climate (including, for example, precipitation and temperature) and we used a multi-model inference procedure to analyse the effects of these components on survival and recruitment in a population of 242 Eurasian beavers over 13 recent years (Campbell et al. 2012b).

Notably, our continuous observations indicated no largescale changes in habitat type, or other apparent causes for changing habitat productivity, which might otherwise explain variation in survival and recruitment. While mean rainfall values influenced both survival and recruitment, the effect of climate variability, in the form of variance in rainfall and temperature and seasonal amplitude in temperature, was also highly influential in a variety of predictive models for survival and recruitment rates. A higher survival rate was linked to a lower coefficient of variation (CV) of precipitation (for kits, juveniles, and dominant adults), lower residual variance of temperature (for dominant adults), and lower mean precipitation (for kits and juveniles).

Greater recruitment was linked (in order of influence) to higher seasonal amplitude of temperature, lower mean precipitation, lower residual variance in temperature, and higher precipitation $\mathrm{CV}$, though the latter probably arose due to individuals from a reservoir of philopatric non-breeding adults migrating into the study area to fill the breeding vacancies created through the reduced adult survival in years of higher precipitation CV. Both climate means and variance thus proved significant to population dynamics; though, overall, components describing variance were more influential than those describing mean values (as we also report for badgers, see Macdonald and Feber (2015: Chapter 4).

Using capture-mark-recapture to monitor 198 individuals over 11 years at the Norwegian study site, we observed lower juvenile body weights after colder winters, indicating that colder winters exert a disproportionately heavy thermoregulatory burden on the smaller younger beavers (Campbell et al. 2013). Warmer spring temperatures were associated with lighter-weight adults, because the shortened spring flush of growth in warm springs reduces the time over which beavers have access to nutritious young growth.

Counter-intuitively for a herbivore, we also observed a negative association between rainfall and body weight in juveniles and adults, and also with reproductive success. Using tree cores to delve into the growth history of the alder Alnus incana, the principal beaver food there, we found a positive relationship with rainfall for trees growing at elevations $>0.5 \mathrm{~m}$ above mean water level, but a negative relationship for trees growing $<0.5 \mathrm{~m}$. We deduced that, while temperature influences beavers at the landscape scale via effects on spring green-up phenology and thermoregulation, rainfall influences beavers at finer spatial scales, for example, with trees near water level prone to water-logging, producing poorer quality forage in wetter years. Unlike most other herbivores, beavers are an obligate aquatic species that utilize a restricted 'central-place' foraging range, limiting their ability to take advantage of better forage growth further from water during wetter years.

These studies reveal a multiplicity of climatic influences on beavers, marked by a reduction in population vital rates and body weights associated with trends in climate that are predicted to continue in the future. For example, weather patterns in Northern Europe are predicted to exhibit increased variability, along with warmer spring weather and wetter summer weather (IPCC 2007), all of which have been shown, in our studies, to correlate with either reduced survival, reduced reproduction, or reduced body weights, or a combination of more than one of these values. This suggests that, in the Norwegian population at least, population growth rate may be impaired in the future. All else being

continued

21 'He makes himself a eunuch, desiring to escape by the loss of his testicles', to which Cicero adds 'They ransom themselves by that part of the body, for which they are chiefly sought'. This, as Geraldus explains, is because 'When the beaver finds he cannot save himself from the pursuit of the dogs who follow him, that he may ransom his body by the sacrifice of a part, he throws away that, which by natural instinct he knows to be the object sought for, and in the sight of the hunter castrates himself, from which circumstance he has gained the name of Castor'. 


\section{Box 16.3 Continued}

equal, those beavers returning to Britain (an island noted for its wet summers and highly changeable weather) may find their viability affected by the changing climate. On the other hand, British winters are mild (a good thing for juveniles) the rivers are empty of conspecific competitors (elsewhere, wolves play an important role in regulating beaver populations, Halley and Rosell 2002), and the vegetation is perhaps well adapted to the wetter and more variable climate, all of which may outweigh any negative effects during the initial colonization period.
Tay will be fascinating and may offer an indication of how well our riparian habitats are connected. Inevitably there are some regions that would either not be connected or take a very long time for beavers to reach.

The possibilities for a beaver re-introduction have not been confined to Scotland. A reintroduction has been also considered for Norfolk in England. Based on land cover assessments of the region, modelling was used to assess the suitablility of the habitat to support a population (South et al. 2001). It was found that Norfolk could support between 18 and 40 beaver families. Establishing other reintroduction sites such as this may help secure beavers' presence in Britain and help wider dispersal that could help further spread of their function to other suitable riparian areas in Britain.

While not all the pros and cons of living with rewilded ecosystems can or should be monetized, society's enthusiasm for rewilding will inescapably be much affected by whether the Knapdale beaver experience comes in as a profit or a loss. In a desk study that anticipated the bottom line of reintroducing beavers to Britain, Campbell et al. (2007) estimated that an individual beaver release site might generate additional local tourism worth $£ 2000000$ a year, whereas costs associated with beaver in Continental Europe rarely rise above $€ 100000$ per annum. Such calculations are, however, notoriously tricky, e.g. disentangling the direct impacts of the beaver from complimentary conservation actions such as riparian woodland regeneration that also offer considerable ecosystem service benefits, such as flood mitigation (National Ecosystem Service Assessment 2011b). Even if the sums currently work against beavers locally, there are nonetheless, increasingly elegant financial mechanisms for those benefiting from regionally and nationally beneficial ecosystem services to pay those currently bearing the cost (Barrett et al. 2013). Dickman et al. (2011), focusing on predators, and thus directly relevant to our example on wolves, describe payments to encourage co-existence between people and wildlife in ways that could easily be adapted to local support for beavers.
New mechanisms, such as biodiversity offsetting and payments for ecosystem services, also offer potential new revenue streams for those providing ecosystem services with wider benefits (Jack et al. 2008; Bull et al. 2012). A notable example of such a scheme includes Water Funds, which launched in 2000 in Ecuador, and has raised $\$ 9.8$ million to invest in the protection and management of the catchement area that includes the Condor Biosphere reserve. The Fund has already supported the planting of 3.5 million trees, explicitly to help provide clean water to Quito (Tallis et al. 2008).

\subsection{Conclusion}

If conservation is to be effective and efficient, investments in the natural world must be subject to some planning at the ecosystem level. An important message behind rewilding is that rich biodiversity with all guilds well represented, including the ones that polarize public opinion, such as large predators, are important components of ecosystem service rich and self-sustaining ecosystems, particularly in core areas. In essence, biodiversity both supports and is supported by the system. In this chapter we initially identified that woodland is an under represented habitat and resource in Britain. Wolves are not dependent on woodland but their function can help to promote tree regeneration through predation of the abundant and diverse large herbivore guild. Wild boar, in contrast, are a woodland orientated species and also provide a rooting service that can help woodland regeneration; although they are unlikely to cause sufficient ground disturbance to promote woodland expansion, they could help to develop and diversify the ecosystem in combination with wolves. Where wild boar are not currently present, wolves may initiate the trophic cascade that increases the suitability of the ecosystem to support wild boar; but where wild boar are already present wolves would aid the limitation of this species and alter their foraging strategy, again helping to support a thriving ecosystem with a well represented 
wooded component. The same applies to beavers, which require a wooded riparian ecosystem to support them. Where they have been reintroduced this habitat already exists, and the addition of beavers offers the opportunity of increasing the diversity of the ecosystem.

We have described a sequence of species reintroductions designed to re-assemble the mammal community that could be used to rewild three processes in Britain. Finding space for large core areas is challenging and the uplands offer the best opportunities for this land sparing approach. If an upland rural community embraced this radical future it would no doubt be a major change from business-as-usual and the benefits to the local rural economy could be significant. The most obvious benefits would be generated through tourism, but concepts such as payments for ecosystem services, carbon, and biodiversity offsetting add potential further monetary value. This might be particularly true in the context of flood alleviation through the rewilding of river catchments. To determine whether this is feasible and desirable requires a full economic, social, and legal assessment, which is beyond the scope of this chapter.

In terms of promoting increased land sharing with Nature, this book has highlighted numerous novel ways of improving society's interaction with Nature. Adding rewilding to this traditional conservation approach should encourage land managers to ask 'What ecological processes can we restore here?', as well as conserving threatened species. This is likely to include paying particular attention to processes such as pollination that are integral to maintaining food production. Finally, rewilding is an emotive concept and one that challenges society's relationship with Nature. More people now live in cities than in rural areas, creating a worrying gap between people and the environment that supports them. Wilding areas near to people, in any way that is appropriate, may also offer a miriad of health and well-being benefits (see Chapter 1, this volume), and will surely help society to maintain that connection to nature.

'Examine each question in terms of what is ethically and aesthetically right, as well as what is economically expedient.' Aldo Leopold

\section{Acknowledgements}

In addition to the editorial insights of Ruth Feber and Eva Raebel, we are grateful for help and suggestions from Ruaraidh Campbell, Kerry Kilshaw, Lauren Harrington, Axel Moehrenschlager, and Chris Newman.
Andrew Kitchener provided helpful comments on an earlier draft. We gratefully acknowledge the support of Paul Lister and the European Nature Trust.

\section{References}

Acs, S., Hanley, N., Dallimer, M., Gaston, K.J., Robertson, P., Wilson, P., and Armsworth, P.R. (2010). The effect of decoupling on marginal agricultural systems: implications for farm incomes, land use and upland ecology. Land Use Policy, 27, 550-563.

Adams, J.R., Vucetich, L.M., Hedrick, P.W., Peterson, R.O., and Vucetich, J.A. (2011). Genomic sweep and potential genetic rescue during limiting environmental conditions in an isolated wolf population. Proceedings of the Royal Society B: Biological Sciences, 278, 3336-3344.

Akçakaya, H.R., Mills, G., and Doncaster, C.P. (2007). The role of metapopulations in conservation. pp. 64-84 In D.W. Macdonald and K. Service, eds., Key Topics in Conservation Biology. Blackwell Publishing, Oxford.

Anderson, C.B., Pastur, G., Lencinas, M.V., Wallem, P.K., Moorman, M.C., and Rosemond, A.D. (2009). Do introduced North American beavers Castor canadensis engineer differently in southern South America? An overview with implications for restoration. Mammal Review, 39, 33-52.

Barrett, C., Bulte, E.H., Ferraro, P., and Wunder, S. (2013). Economic instruments for nature conservation. pp. 59-73 In D.W. Macdonald and K.J. Willis, eds., Key Topics in Conservation Biology 2. Wiley.

Belyea, L.R. (2004). Beyond ecological filters: Feedback networks in the assembly and restoration of community structure. pp. 115-132 In V.M. Temperton, R.J. Hobbs, T. Nuttle, and S. Halle, eds., Assembly Rules and Restoration Ecology: Bridging the Gap Between Theory and Practice. Island Press, Washington.

Benyus, J.M. (2009). Biomimicry. HarperCollins.

Breitenmoser U, et al. (2010) The changing impact of predation as a source of conflict between hunters and reintroduced lynx in Switzerland. Biology and Conservation of Wild Felids, eds., Macdonald D.W. and Loveridge A.J. Oxford University Press, Oxford.

British Wild Boar (2015). <http: / / www.britishwildboar.org. uk/index.htm?nuisance.html>. Accessed Feb 2015.

Bull, J., Sandom, C., Ejrnæs, R., Macdonald, D.W., and Svenning, J.C. (in prep). Barriers can ensure the restoration of ecosystem function in the case of large predator reintroductions.

Bull, J. W., Suttle, K.B., Gordon, A., Singh, N.J., and MilnerGulland, E. (2012). Biodiversity offsets in theory and practice. Oryx, 47 (03), 369-380.

Burns, F., Eaton, M.A., Gregory, R.D., et al. (2013). State of Nature report. The State of Nature partnership.

Butts, W.L. (2001). Beaver ponds in upstate New York as a source of anthropophilic mosquitoes. Journal of the American Mosquito Control Association, 17, 85-86. 
Campbell, R., Dutton, A., and Hughes, J. (2007). Economic Impacts of the Beaver. University of Oxford, Oxford.

Campbell, R., Harrington, A., Ross, A., and Harrington, L. (2012a). Distribution, population assessment and activities of beavers in Tayside., Scottish Natural Heritage Commissioned Report No.-540.

Campbell, S. and Hartley, G. (2010). Wild Boar Distribution in Scotland. Science and advice for Scottish Agriculture, Edinburgh.

Campbell, R.D., Newman, C., Macdonald, D.W., and Rosell, F. (2013). Proximate weather patterns and spring green-up phenology effect Eurasian beaver (Castor fiber) body mass and reproductive success: the implications of climate change and topography. Global Change Biology, 19(4), 1311-1324.

Campbell, R.D., Nouvellet, P., Newman, C., Macdonald, D.W., and Rosell, F. (2012b). The influence of mean climate trends and climate variance on beaver survival and recruitment dynamics. Global Change Biology, 18, 2730-2742.

Collen, P. and Gibson, R. (2000). The general ecology of beavers (Castor spp.), as related to their influence on stream ecosystems and riparian habitats, and the subsequent effects on fish, a review. Reviews in fish biology and fisheries, 10, 439-461.

Creel, S., Becker, M., Durant, S., et al. (2013). Conserving large populations of lions-the argument for fences has holes. Ecology Letters. 16(11), 1413-e3

Cullingham, C. I. and Moehrenschlager, A. (2013). Temporal analysis of genetic structure to assess population dynamics of reintroduced swift foxes. Conservation Biology, 27(6), 1389-1398.

Deer Commission Scotland, Forestry Commission Scotland, Scottish Natural Heritage, and Scottish Executive Environment and Rural Affairs Department (2004). Joint agency statement and guidance on deer fencing. <http:/ / www.snh.gov.uk/docs/C249890.pdf>.

Defra (2008). Feral wild boar in England: An action plan. Department for Environment, Food and Rural Affairs, London.

Defra (2011). The natural choice: securing the value of nature. Department of Environment, Food and Rural Affairs.

Deinet, S., Ieronymidou, C., McRae, L., Burfield, I.J, Foppen, R.P., Collen, B., and Böhmm, M. (2013). Wildlife comeback in Europe: The recovery of selected mammal and bird species. Final report to Rewilding Europe by ZSL, Birdlife International and European Bird Census Council. London, UK:ZSL.

Dickman, A.J., Macdonald, E.A., and Macdonald, D.W. (2011). A review of financial instruments to pay for predator conservation and encourage human, carnivore coexistence. Proceedings of the National Academy of Sciences 108, 13937-13944.

Duffield, J.W., Neher, C.J., and Patterson, D.A. (2008). Wolf recovery in Yellowstone Park: Visitor attitudes, expenditures, and economic impacts. Yellowstone Science 16, 20-25.
Enserink, M. and Vogel, G. (2006). The carnivore comeback. Science, 314, 746-749.

Estes, J.A., Terborgh, J., Brashares, J.S., et al. (2011). Trophic downgrading of planet Earth. Science, 333, 301-306.

Fischer, J., Brosi, B., Daily, G.C., et al. (2008). Should agricultural policies encourage land sparing or wildlife-friendly farming? Frontiers in Ecology and the Environment, 6, 380-385.

Forestry Commission (2012). Forestry Statistics 2012Environment-Ancient and semi-natural woodland.

Fritts, S.H. and Carbyn, L.N. (1995). Population viability, nature reserves, and the outlook for gray wolf conservation in North America. Restoration Ecology, 3, 26-38.

Fritzemeier, J., Teuffert, J., Greiser-Wilke, I., Staubach, C., Schlüter, H., and Moennig, V. (2000). Epidemiology of classical swine fever in Germany in the 1990s. Veterinary Microbiology, 77, 29-41.

Fuller, R. and Gough, S. (1999). Changes in sheep numbers in Britain: implications for bird populations. Biological Conservation, 91, 73-89.

Gill, R. and Fuller, R.J. (2007). The effects of deer browsing on woodland structure and songbirds in lowland Britain. Ibis, 149, 119-127.

Gill, R. and Morgan, G. (2010). The effects of varying deer density on natural regeneration in woodlands in lowland Britain. Forestry, 83, 53-63.

Goulding, M. (2014). <http://www.britishwildboar.org. uk>. Accessed June 2014

Goulding, M.J., Smith, G., and Baker, S. (1998). Current Status and Potential Impact of Wild Boar (Sus scrofa) in the English Countryside: A Risk Assessment. Conservation Management Division C, MAFF.

Green, R.E., Cornell, S.J., Scharlemann, J.r.P., and Balmford, A. (2005). Farming and the fate of wild nature. Science, 307, 550-555.

Halley, D. and Rosell, F. (2002). The beaver's reconquest of Eurasia: status, population development and management of a conservation success. Mammal Review, 32(3), 153-178.

Hambler, C., Henderson, P.A., and Speight, M.R. (2011). Extinction rates, extinction-prone habitats, and indicator groups in Britain and at larger scales. Biological Conservation, 144, 713-721.

Harkonen, S. (1999). Forest damage caused by the Canadian beaver (Castor canadensis) in South Savo, Finland. Silva Fennica, 33, 247-259.

Harrington, L.A., Feber, R., and Macdonald, D.W. (2012). The Scottish Beaver Trial: Ecological monitoring of the European beaver Castor fiber and other riparian mammals-Second Annual Report 2011. Scottish Natural Heritage Commissioned Report No. 510.

Harrington, L.A., Feber, R. and Macdonald, D.W. (2013). The Scottish Beaver Trial: Ecological monitoring of the European beaver Castor fiber and other riparian mammals-Third Annual Report 2012. Scottish Natural Heritage Commissioned Report No. 553.

Hayward, M.W. and Kerley, G.I.H. (2009). Fencing for conservation: Restriction of evolutionary potential or a 
riposte to threatening processes? Biological Conservation, 142, 1-13.

Hetherington DA (2005). The feasibility of reintroducing the Eurasian lynx, Lynx lynx to Scotland. D. Phil Thesis (University of Aberdeen).

Hetherington, D.A., Lord, T.C., and Jacobi, R.M. (2006). New evidence for the occurrence of Eurasian lynx (Lynx $\operatorname{lyn} x)$ in medieval Britain. Journal of Quaternary Science, 21(1), 3-8.

Hetherington, D.A., Miller, D.R., Macleod, C.D., and Gorman, M.L. (2008). A potential habitat network for the Eurasian lynx Lynx lynx in Scotland. Mammal Review, 38(4), 285-303.

Hilborn, R., Arcese, P., Borner, M., Hando, J., Hopcraft, G., Loibooki, M., Mduma, S., and Sinclair, A.R. (2006). Effective enforcement in a conservation area. Science, 314, 1266-1266.

Hobbs, R. (2009). Woodland restoration in Scotland: Ecology, history, culture, economics, politics and change. Journal of Environmental Management, 90, 2857-2865.

Hobbs, R.J. and Huenneke, L.F. (1992). Disturbance, Diversity, and Invasion: Implications for Conservation. Conservation Biology, 6, 324-337.

Hodder, K. H., Buckland, P.C., Kirby, K.K., and Bullock, J.M. (2009). Can the mid-Holocene provide suitable models for rewilding the landscape in Britain? British Wildlife, 20, 4-1.

IPCC (2007). Climate Change 2007: Working Group II: Impacts, Adaptation and Vulnerability. Cambridge University Press.

IUCN and UNEP-WCMC (2011). The World Database on Protected Areas (WDPA). In UNEP-WCMC, editor., Cambridge, UK.

Jack, B. K., Kousky, C., and Sims, K.R.E. (2008). Designing payments for ecosystem services: Lessons from previous experience with incentive-based mechanisms. Proceedings of the National Academy of Sciences, 105, 9465-9470.

Jones, S., Gow, D., Lloyd Jones, A., Campbell-Palmer, R. (2013). The battle for British beavers. British Wildlife, 24, 381-392.

Jonker, S.A., Muth, R.M., Organ, J.F., Zwick, R.R., and Siemer, W.F. (2006). Experiences with beaver damage and attitudes of Massachusetts residents toward beaver. Wildlife Society Bulletin, 34, 1009-1021.

Kass, G., Shaw, R., Tew, T., and Macdonald, D. (2011). Securing the future of the natural environment: using scenarios to anticipate challenges to biodiversity, landscapes and public engagement with nature. Journal of Applied Ecology, 48(6), 1518-1526.

Keddy, P. and Weiher, E. (2001). Introduction: The scope and goals of research on assembly rules. pp. 1-22 In E. Weiher and P. Keddy, eds., Ecological Assembly Rules: Perspectives, Advances, Retreats. Cambridge University Press, Cambridge.

Kitchener, A. and Conroy, J. (1997). The history of the Eurasian beaver Castor fiber in Scotland. Mammal Review, 27, 95-108.
Kotulski, Y. and König, A. (2008). Conflicts, crises and challenges: wild boar in the Berlin City-a social empirical and statistical survey. Natura Croatica, 17, 233-246.

Lawton, J.H., Brotherton, P.N.M., Brown, V.K., et al. (2010). Making Space for Nature: a review of England's wildlife sites and ecological network. Report to Defra. <http:// archive.defra.gov.uk/environment/biodiversity / documents /201009space-for-nature.pdf $>$.

Leaper, R., Massei, G., Gorman, M.L., and Aspinall, R. (1999). The feasibility of reintroducing Wild Boar (Sus scrofa) to Scotland. Mammal Review, 29, 239-259.

Linnell, J., Salvatori, V., and Boitani, L. (2008). Guidelines for population level management plans for large carnivores in Europe. A Large Carnivore Initiative for Europe report prepared for the European Commission.

Luck, G. W., Harrington, R., Harrison, P.A., et al. (2009). Quantifying the Contribution of Organisms to the Provision of Ecosystem Services. Bioscience, 59, 223-235.

Macarthur, E. (2013). <http://www.ellenmacarthurfoundation.org >.

MacArthur, R.H. and Wilson, E.O. (1967). The Theory of Island Biogeography. Princeton University Press.

Macdonald, D. (2009). Lessons Learnt and Plans Laid: Seven Awkward Questions for the Future of Reintroductions. In M. Hayward and M. Somers, eds., Reintroduction of TopOrder Predators. Wiley-Blackwell, Hoboken, NJ, USA.

Macdonald, D.W., Boitani, L., Dinerstein, E., Fritz, H., and Wrangham, R. (2013). Conserving large mammals: are they a special case? In D.W. Macdonald and K.J. Willis, eds., Key Topics in Conservation Biology 2. Wiley Publications.

Macdonald, D. and Burnham, D. (2010). The state of Britain's mammals a focus on invasive species. People's trust for endangered species.

Macdonald, D.W. and Feber, R.E., eds., (2015). Wildlife Conservation on Farmland. Conflict in the Countryside. Oxford University Press, Oxford.

Macdonald, D. and Johnson, P. (2000). Farmers and the custody of the countryside: trends in loss and conservation of non-productive habitats 1981-1998. Biological Conservation, 94, 221-234.

Macdonald, D., Mace, G., and Rushton, S. (2000). British mammals: is there a radical future? In A. Entwistle and N. Dunstone, eds., Priorities for the Conservation of Mammalian Diversity: Has the Panda Had its Day? Cambridge University Press.

Macdonald, D.W. and Tattersall, F. (2001). Britain's Mammals: The Challenge for Conservation. The People's Trust for Endangered Species, Mammals Trust UK.

Macdonald, D. W., Tattersall, F.H., Brown, E.D., and Balharry, D. (1995). Reintroducing the European Beaver to Britain: nostalgic meddling or restoring biodiversity? Mammal Review, 25, 161-200.

Manning, A. D., Gordon, I.J., and Ripple, W.J. (2009). Restoring landscapes of fear with wolves in the Scottish Highlands. Biological Conservation, 142, 2314-2321. 
Maroo, S. and Yalden, D. (2000). The Mesolithic mammal fauna of Great Britain. Mammal Review, 30, 243-248.

Mech, L. D. (1966). The Wolves of Isle Royale. University of Minnesota.

Mech, D. and Boitani, L. (2003). Wolves: Behaviour, Ecology E Conservation. The University of Chicago Press, Chicago.

Miljominsteriet Naturstyrelsen. (2013). Vildtforvaltningsrådet er klar med ulveplan.

Mitchell, F.J.G. (2005). How open were European primeval forests? Hypothesis testing using palaeoecological data. Journal of Ecology, 93, 168-177.

Moehrenschlager, A., List, R., and Macdonald, D.W. (2007). Escaping intraguild predation: Mexican kit foxes survive while coyotes and golden eagles kill Canadian swift foxes. Journal of Mammalogy, 88, 1029-1039.

Moehrenschlager, A. and Macdonald, D.W. (2003). Movement and survival parameters of translocated and resident swift foxes Vulpes velox. Animal Conservation, 6, 199-206.

Moore, B.D., Sim, D.A., and Iason, G.R. (2013). The Scottish Beaver Trial: Woodland monitoring 2011. Scottish Natural Heritage Commissioned Report No. 525.

Moran, D. and Hanley-Nickolls, R. (2012). The Scottish Beaver Trial: Socio-economic monitoring-First report 2011. Scottish Natural Heritage Commissioned Report No.482.

Morton, D., Rowland, C., Wood, C., Meek, L., Marston, C., Smith, G., Wadsworth, R., and Simpson, I.C. (2011). Final report for LCM2007-the new UK Land Cover Map. Centre for Ecology \& Hydrology (Natural Environmental Research Council)

Müller-Schwarze, D. and Sun, L. (2003). The Beaver: Natural History of a Wetlands Engineer. Cornell University Press.

National Ecosystem Service Assessment. (2011a). The UK national ecosystem service assessment. UNEP-WCMC, Cambridge.

National Ecosystem Service Assessment. (2011b). The UK national ecosystem service assessment: Woodlands. UNEP-WCMC, Cambridge.

National Parks UK. (2012). National Parks. <http://www. nationalparks.gov.uk/>

Navarro, L. and Pereira, H. (2012). Rewilding abandoned landscapes in Europe. Ecosystems, 15, 900-912.

Nilsen, E.B., Milner-Gulland, E.J., Schofield, L., Mysterud, A., Stenseth, N.C., and Coulson, T. (2007). Wolf reintroduction to Scotland: public attitudes and consequences for red deer management. Proceedings of the Royal Society B: Biological Sciences, 274, 995-1003.

Odden J, Linnell, J.D., and Andersen, R. (2006). Diet of Eurasian lynx, Lynx lynx, in the boreal forest of southeastern Norway: the relative importance of livestock and hares at low roe deer density. Eur J Wildl Res 52(4):237-244.

Packer, C., Loveridge, A. Canney, S., et al. (2013). Conserving large carnivores: dollars and fence. Ecology Letters, 16, 635-641.

Patten, C. (2009). What Next?: Surviving the Twenty-first Century. Penguin Adult.
Peterson, R.O. and Page, R.E. (1988). The rise and fall of Isle Royale Wolves, 1975-1986. Journal of Mammalogy, 69, 89-99.

Peterson, R.O., Thomas, N.J., Thurber, J.M., Vucetich, J.A., and Waite, T.A. (1998). Population limitation and the wolves of Isle Royale. Journal of Mammalogy, 79, 828-841.

Pollock, M.M., Naiman, R.J., and Hanley, T.A. (1998). Plant species richness in riparian wetlands-a test of biodiversity theory. Ecology, 79, 94-105.

Power, M. E., Tilman, D., Estes, J.A., Menge, B.A., Bond, W.J., Mills, L.S., Daily, G., Castilla, J.C., Lubchenco, J., and Paine, R.T. (1996). Challenges in the Quest for Keystones. Bioscience, 46, 609-620.

Richardson, P. (2013). Wolf-watching in Spain. Financial Times. March 2013, <http://www.ft.com/cms/s/2/c341b948947c43-11e2-99f0-00144feabdc0.html\#axzz33UPM38By>

Ripple, W.J. and Beschta, R.L. (2012). Trophic cascades in Yellowstone: The first 15 years after wolf reintroduction. Biological Conservation, 145, 205-213.

Robinson, R. (2009). Invasive and problem ferns: a European perspective. International Urban Ecology, 4, 83-91.

Rolauffs, P., Hering, D., and Lohse, S. (2001). Composition, invertebrate community and productivity of a beaver dam in comparison to other stream habitat types. Hydrobiologia, 459, 201-212.

Rosell, F., Bozsér, O., Collen, P., and Parker H. (2005). Ecological impact of beavers Castor fiber and Castor canadensis and their ability to modify ecosystems. Mammal Review, 35, 248-276.

Rosell, F., Rosef, O., and Parker, H. (2001). Investigations of waterborne pathogens in Eurasian beaver (Castor fiber) from Telemark County, southeast Norway. Acta Veterinaria Scandinavica, 42, 479-482.

Sandom, C.J., Bull, J., Canney, S., and Macdonald, D. (2012). Exploring the value of wolves (Canis lupus) in landscapescale fenced reserves for ecological restoration in the Scottish Highlands. pp. 245-276 In M. Somers and M. Hayward, eds., Fencing for Conservation: Restriction of Evolutionary Potential or a Riposte to Threatening Processes? Springer, New York.

Sandom, C., Dalby, L., Fløjgaard, C., et al. (2013a). Mammal predator and prey species richness are strongly linked at macroscales. Ecology, 94, 1112-1122.

Sandom, C.J., Donlan, C.J., Svenning, J.C., and Hansen, D.M. (2013b). Rewilding. In D.W. Macdonald and K.J. Willis, eds., Key Topics in Conservation Biology 2. Blackwell Publishing, Oxford.

Sandom, C., Ejrnæs, R., Hansen, M.D.D., and Svenning, J.-C. (2014b). High herbivore density associated with vegetation diversity in interglacial ecosystems. Proceedings of the National Academy of Sciences, 111(11), 4162-4167.

Sandom, C., Faurby, S., Sandel, B., and Svenning, J.-C. (2014a) Global late Quaternary megafauna extinctions linked to humans, not climate change. Proceedings of the Royal Society B: Biological Sciences 281(1787). 
Sandom, C.J., Hughes, J., and Macdonald, D.W. (2013c). Rewilding the Scottish Highlands: do wild boar, Sus scrofa, use a suitable foraging strategy to be effective ecosystem engineers? Restoration Ecology, 21, 336-343.

Sandom, C. J., Hughes, J., and Macdonald, D.W. (2013d). Rooting for rewilding: quantifying wild boar's Sus scrofa rooting rate in the Scottish Highlands. Restoration Ecology, 21, 329-335.

Sandom, C., Hughes, J., and Macdonald, D.W. (in prep-a). Rewilding with an ecosystem engineer: Can wild boar Sus scrofa promote woodland regeneration and control Bracken Pteridium aquilinum in the Scottish Highlands?

Schley, L., Dufrêne, M., Krier, A., and Frantz, A. (2008). Patterns of crop damage by wild boar (Sus scrofa) in Luxembourg over a 10-year period. European Journal of Wildlife Research, 54, 589-599.

Schley, L. and Roper, T.J. (2003). Diet of wild boar Sus scrofa in Western Europe, with particular reference to consumption of agricultural crops. Mammal Review, 33, 43-56.

SER (2004). The SER International Primer on Ecological Restoration. Society for the Ecological Restoration International.

Sims, N. (2005). The ecological impacts of wild boar rooting in East Sussex. D. Phil.Thesis University of Sussex.

Skewes, O., Gonzalez, F., Olave, R., Ávila, A., Vargas, V., Paulsen, P., and König, H.E. (2006). Abundance and distribution of American beaver, Castor canadensis (Kuhl 1820), in Tierra del Fuego and Navarino islands, Chile. European Journal of Wildlife Research, 52, 292-296.

Smith, D.W., Peterson, R.O., and Houston, D.B. (2003). Yellowstone after wolves. Bioscience, 53, 330-340.

Soulé, M.E. and Noss, R.F. (1998). Rewilding and biodiversity: Complementary goals for continental conservation. Wild Earth, 8.

South, A., Rushton, S., Macdonald, D. and Fuller, R. (2001). Reintroduction of the European beaver (Castor fiber) to Norfolk, UK: a preliminary modelling analysis. Journal of Zoology, 254, 473-479.

Stahl, P., Vandel, J., Herrenschmidt, V., and Migot, P. (2001a). The effect of removing lynx in reducing attacks on sheep in the French Jura Mountains. Biological Conservation, 101, 15-22.

Stahl, P., Vandel, J.M., Rutte, S., Coat, L., Coat, Y., and Balestra, L. (2002). Factors affecting lynx predation on sheep in the French Jura. Journal of Applied Ecology, 39, 204-216.

Svenning, J.-C. (2002). A review of natural vegetation openness in north-western Europe. Biological Conservation, 104, 133-148.

Sykes, N. (2004). The introduction of fallow deer to Britain: a zooarchaeological perspective. Environmental Archaeology, 9, 75-83.

Tallis, H., Kareiva, P., Marvier, M., and Chang, A. (2008). An ecosystem services framework to support both practical conservation and economic development. Proceedings of the National Academy of Sciences 105, 9457-9464.
Tattersall, F. and Macdonald, D. (1995). A Review of the Direct and Indirect Costs of Re-introducing the European Beaver (Castor fiber) to Scotland. Report, Contract No. SNH/110/95 IBB. WildCRU, Oxford.

TEEB (2010). The Economics of Ecosystems and Biodiversity: Mainstreaming the Economics of Nature: A synthesis of the approach, conclusions and recommendations of The Economics of Ecosystems and Biodiversity (TEEB).

Terborgh, J. and Estes, J.A., eds. (2010). Trophic Cascades: Predators, Prey, and Changing Dynamics of Nature. Island Press, Washington DC.

Thomsen, L.R., Campbell, R.D., and Rosell, F. (2007). Tooluse in a display behaviour by Eurasian beavers (Castor fiber). Animal Cognition, 10, 477-482.

Vera, F.W.M. (2000). Grazing Ecology and Forest History. CABI Pub., New York.

Vera, F. (2009). Large-scale nature development-the Oostvaardersplassen. British Wildlife, 20, 28-36.

Vucetich, J. A., Nelson, M.P., and Peterson, R.O. (2012). Should Isle Royale wolves be reintroduced? A case study on wilderness management in a changing world. Pages 126-147 In George Wright Forum.

Vucetich, J.A. and Peterson, R.O. (2004). The influence of topdown, bottom-up and abiotic factors on the moose (Alces alces) population of Isle Royale. Proceedings of the Royal Society of London. Series B: Biological Sciences 271, 183-189.

Ward, A.I. (2005). Expanding ranges of wild and feral deer in Great Britain. Mammal Review, 35, 165-173.

Warren, C R. (2009). Managing Scotland's Environment. Edinburgh University Press, Edinburgh.

Westbrook, C., Cooper, D., and Baker, B. (2011). Beaver assisted river valley formation. River Research and Applications, 27, 247-256.

Whitehouse, N. J. and Smith, D. (2010). How fragmented was the British Holocene wildwood? Perspectives on the 'Vera' grazing debate from the fossil beetle record. Quaternary Science Reviews, 29, 539-553.

Willby, N.J., Casas Mulet, R. and Perfect, C. (2011).The Scottish Beaver Trial: Monitoring and further baseline survey of the aquatic and semi-aquatic macrophytes of the lochs 2009. Scottish Natural Heritage Commissioned Report No. 455.

Widstrand, S. (2013). Is there really any money in wildlife watching?- - g global and European perspective. In Wild10. Rewilding Europe, Salamanca.

Wright, J. P., Jones, C.G., and Flecker, A.S. (2002). An ecosystem engineer, the beaver, increases species richness at the landscape scale. Oecologia, 132, 96-101.

Yalden, D. (1999). The History of British Mammals. Academic Press, London.

Yalden, D. and Barrett, P. (1999). The History of British Mammals. T \& A D Poyser.

Zhou, Y., Newman, C., Chen, J., Xie, Z., and Macdonald, D.W. (2013). Anomalous, extreme weather disrupts obligate seed dispersal mutualism: snow in a subtropical forest ecosystem. Global Change Biology, 19, 2867-2877. 